\title{
O patrimônio geológico do município de Florianópolis, Ilha de Santa Catarina, Santa Catarina, Brasil: inventário dos geossítios
}

\author{
Cristina COVELLO ${ }^{1}$, Norberto Olmiro HORN FILHOํㅛ \& José BRILHA ${ }^{2}$
}

\begin{abstract}
${ }^{1}$ Programa de Pós-graduação em Geografia, Departamento de Geociências, Centro de Filosofia e Ciências Humanas, Universidade Federal de Santa Catarina. Campus Universitário Trindade, CEP: 88.040-900, Florianópolis, SC, Brasil (cristainis@gmail.com, norberto.horn@ufsc.br).

${ }^{2}$ Instituto de Ciências da Terra, Polo da Universidade do Minho. Campus de Gualtar, CEP 4710-057, Braga, Portugal (jbrilha@dct.uminho.pt).
\end{abstract}

\begin{abstract}
Covello, C., Horn Filho, N.O. \& Brilha, J. 2018. 0 patrimônio geológico do município de Florianópolis, Ilha de Santa Catarina, Brasil. Pesquisas em Geociências, 45: e0668.
\end{abstract}

DOI: https://doi.org/10.22456/1807-9806.85646

\begin{abstract}
Resumo. 0 município de Florianópolis tem $45 \%$ do seu território designado como área protegida. Essas áreas estão sendo fragmentadas e degradadas devido ao desenvolvimento de infraestruturas urbano-turísticas. Como consequência, vem ocorrendo a redução da diversidade de ecossistemas e de patrimônio natural, incluindo a perda de geodiversidade e patrimônio geológico, que ainda tem um baixo reconhecimento pelo município. Este artigo apresenta o resultado de um inventário visando a identificação de geossítios representativos da evolução geológica e geomorfológica do município de Florianópolis. Vinte geossítios foram identificados a partir da revisão da literatura geológica e de sugestões feitas por especialistas que pesquisaram a área de estudo. Nove correspondem à categoria geomorfológica "morros, montanhas e elevações" e onze à categoria "planície costeira". A maioria dos sítios tem fácil acesso, é citada em artigos científicos e embora esteja em áreas protegidas, sua conservação não está garantida. Constatou-se que além do desenvolvimento urbano-turístico, a falta de fiscalização ambiental e do plano de manejo nas áreas protegidas também é uma ameaça à conservação do patrimônio geológico. A conscientização das comunidades de Florianópolis para a importância do patrimônio geológico por meio de ações educativas é essencial, porque só protegemos o que conhecemos.
\end{abstract}

Palavras-chave. geologia, geodiversidade, sítios geológicos, geoconservação.

\begin{abstract}
The geological heritage of the municipality of Florianó polis, Santa Catarina ISLAND, SANTA CATARINA, BRAZIL: INVENTORY OF GEOSITES. The municipality of Florianópolis has $45 \%$ of its territory designated as protected area. These areas are being fragmented and degraded due to the development of urban-tourist infrastructures. Therefore, there has been a reduction in the diversity of ecosystems and natural heritage, including the loss of geodiversity and geological heritage, which still has a low recognition by the municipality. This article presents the result of an inventory carried out aiming the identification of geosites representative of the geological and geomorphological evolution of Florianópolis municipality. Twenty geosites were identified from the review of the geological literature and from suggestions made by experts who have researched the study area. Nine correspond to the geomorphological framework "hills, mountains and elevations" and eleven to the "coastal plain" framework. Most sites have easy access, are cited in scientific articles and, although they are inside protected areas, their conservation is not guaranteed. It was found that in addition to the urban-tourist development, the lack of environmental inspection and management plans in protected areas are also a threat to the conservation of geological heritage. The raises of awareness of the communities of Florianópolis for the importance of geological heritage through educational actions are essential, because we only protect what we know.
\end{abstract}

Keywords. geology, geodiversity, geological sites, geoconservation. 


\section{Introdução}

O município de Florianópolis, capital do Estado de Santa Catarina, tem como território a Ilha de Santa Catarina (área de $424 \mathrm{~km}^{2}$ ) e uma pequena parte continental (área de $11,9 \mathrm{~km}^{2}$ ), que já se encontra completamente urbanizada. Possui uma paisagem de beleza ímpar, marcada pela presença de maciços rochosos interligados por sedimentos da planície costeira que, associados ao clima, possibilitaram a formação de uma diversidade de ecossistemas costeiros. Com 117 praias arenosas, lagunas, lagoas, dunas, restingas, costões, marismas e mangues, este território é o atrativo de milhares de turistas e um dos motivos da fixação de parte destes.

Desde 1970, quando iniciou o desenvolvimento de políticas públicas que incentivaram o setor terciário, até os dias atuais, a população do município triplicou, atingindo aproximadamente 500 mil habitantes em 2015 (IBGE, 2016). Em relação ao turismo, no ano de 2012 foram registrados mais de 590 mil turistas, ou seja, a população de Florianópolis duplica no verão, chegando a mais de um milhão de pessoas (SANTUR, 2012).

Contudo, a Ilha de Santa Catarina, que recebe a maior parte do fluxo turístico e detém a maioria da população do município, tem $45 \%$ do seu território designado como Área de Preservação Permanente. Estas áreas, fragmentadas pela expansão dos núcleos urbanos e vias de acesso, estão sendo degradadas para construção de infraestruturas urbano-turísticas (Ferreti, 2013). Consequentemente, a diversidade de ecossistemas e patrimônio natural está sendo descaracterizada ou suprimida, o que acarreta na perda da geodiversidade e patrimônio geológico, ainda pouco reconhecido pela sociedade.

A geodiversidade é a variedade de ambientes e elementos geológicos, geomorfológicos e pedológicos, que dão origem as paisagens e são o suporte da vida da Terra (Gray, 2004). Porém, por ser inviável proteger toda a geodiversidade, pois muitos dos seus elementos são utilizados como recursos pela sociedade, a seleção dos elementos da geodiversidade mais importantes (inventário) está incluída no processo de geoconservação (Gray, 2004; Brilha, 2005).
A geoconservação consiste na conservação de locais onde foram reconhecidos valores singulares aos elementos da geodiversidade, como a presença de formações rochosas específicas, processos geológicos ou geomorfológicos peculiares e representativos. Esses locais, quando possuem valor científico, são denominados de geossítios e o conjunto de geossítios existentes numa região, materializa o patrimônio geológico. Quando apresentam apenas valor educativo, turístico e/ou cultural são designados por sítios de geodiversidade (Brilha, 2016).

Além de visar assegurar a preservação dos elementos geológicos mais relevantes, permitindo seu legado às próximas gerações, a geoconservação também tem como objetivo aproveitar seu potencial e utilizá-lo para o desfrute da população, incluindo a possibilidade de usá-lo para promover o desenvolvimento sustentável (Urquí, 2012).

Para atingir esse fim, foram estabelecidas estratégias de geoconservação que definem a execução de uma metodologia de trabalho: inventário, avaliação quantitativa, conservação, interpretação e promoção, e a monitorização dos sítios, as quais devem ser realizadas em etapas sucessivas (Brilha, 2005; Henriques et al., 2011). A primeira etapa, o inventário, consiste na identificação e seleção dos geossítios, pois só se protege/conserva o que se conhece.

Apesar de já terem sido realizados mapeamentos geológicos e geomorfológicos em Florianópolis, principalmente na Ilha de Santa Catarina, como de Herrmann \& Rosa (1991), Caruso Jr. (1993), Cruz (1998), Luiz (2004), Horn Filho \& Livi (2014) e Tomazzoli \& Pellerin (2014), ainda não há um levantamento sistemático da geodiversidade que elenque os sítios mais importantes e representativos da evolução geológica do município, com importância científica e que, por esta razão, devem ser preservados.

Além disso, o Plano Diretor de Florianópolis, instituído pela Lei Complementar no 482 , de janeiro de 2014, prevê na Seção VII, Artigo 137, a necessidade de inventariar o patrimônio geológico do município, para resguardar a geodiversidade, bem como promover o acesso público, o estudo e a divulgação de seus elementos (Florianópolis, 2014). 
Este artigo apresenta as etapas desenvolvidas e o resultado de inventário realizado com o objetivo de identificar os geossítios do território de Florianópolis, representativos de sua evolução geológica e geomorfológica, bem como sugestões iniciais para a sua gestão. Pretende-se, assim, conhecer o patrimônio geológico do município e propor às entidades públicas a implementação de estratégias de geoconservação que visarão promover a geodiversidade local, a educação em geociências e o geoturismo, como também contribuir com o ordenamento territorial do município e com o estabelecimento de planos de gestão da geodiversidade.

As propostas e planos de gestão são decorrentes das avaliações quantitativas, segunda etapa das estratégias de geoconservação, porém através do inventário já foi possível constatar problemas e apresentar sugestões de gestão. Entretanto, somente com a avaliação da fragilidade e vulnerabilidade de cada um dos sítios em relação aos fatores naturais e/ou antrópicos, será possível reconhecer os que se encontram sob maior risco e, dessa forma, contribuir para a definição de estratégias de gestão desses locais.

\section{2 Área, materiais e métodos}

\subsection{Breve descrição geológico-geomorfológica da área de estudo}

Florianópolis localiza-se na região Sul do Brasil, no setor Central do litoral do Estado de Santa Catarina, entre os paralelos $27^{\circ} 21^{\prime}$ e $27^{\circ} 50^{\prime}$ de latitude sul e entre os meridianos $48^{\circ} 20^{\prime}$ e $48^{\circ} 35^{\prime}$ de longitude oeste. A Ilha de Santa Catarina e o continente são separados pela Baía de Florianópolis, compartimentada nas baías Norte e Sul, mas interligados através de um estreito de cerca de $500 \mathrm{~m}$ de largura, sobre o qual estendem-se as três pontes de acesso ao continente.

Os principais trabalhos que abordaram a geologia de Florianópolis são: Martin et al. (1988); Zanini et al. (1997), Caruso Jr. (1993), Horn Filho \& Livi (2013), Wildner et al. (2014) e Tomazzoli \& Pellerin $(2014,2015)$. Estes últimos autores realizaram o mapeamento geológico da Ilha de Santa Catarina, na escala 1:50.000, elaborado sob base cartográfica em escala 1:2.000, o que resultou num elevado grau de detalhamento geológico de suas unidades, com cerca de 5100 pontos-afloramento na área total da ilha. A geomorfologia foi mapeada e descrita por Herrmann \& Rosa (1991), Cruz (1998), Luiz (2004) e GERCO (2010).

Apesar de não existir um mapeamento geológico e geomorfológico detalhado da parte continental de Florianópolis, a geodiversidade é semelhante à da ilha. A Ilha de Santa Catarina é considerada uma ilha continental devido às similaridades com as paisagens costeiras circunvizinhas das áreas continentais, o que sugere que a mesma e o continente estiveram unidos quando o nível do mar se encontrava abaixo do atual (Cruz, 1998; Horn Filho, 2006).

O território de Florianópolis é constituído por rochas antigas do Ciclo Brasiliano, diques cretáceos do Enxame de Diques Florianópolis e depósitos quaternários continentais e transicionais. Do ponto de vista geomorfológico, pode ser dividido em dois domínios fundamentais: a) morros, montanhas e elevações; e b) planícies costeiras, que interligam essas elevações.

O domínio de morros, montanhas e elevações é constituído por migmatitos do Complexo Águas Mornas, Granito São Pedro de Alcântara, Granito Ilha, e por rochas plutonovulcânicas ácidas que compõem a Suíte Cambirela (rochas piroclásticas e Granito Itacorubi). Estes litotipos são seccionados por diques básicos, ácidos e intermediários do Enxame de Diques Florianópolis, bem como por rochas cataclásticas e diversas falhas/ fraturas (Tomazzoli \& Pellerin, 2015).

No domínio da planície costeira, os sedimentos cenozoicos estão ancorados nos maciços rochosos. Os tipos de sedimentos variam conforme o ambiente de deposição - colúvio-aluvionar (continental); marinho, eólico, lagunar e estuarino, todos os últimos transicionais. Na planície costeira de Florianópolis foram mapeados os seguintes depósitos: Depósito eólico, Depósito lagunar praial, Depósito lagunar, Depósito marinho praial, Depósito paludial, Depósito de baía, Depósito flúvio-lagunar, estes do Holoceno; e ainda Depósito eólico do Pleistoceno superior; Depósito aluvial, Depósito de leque aluvial e Depósito coluvial, estes do Quaternário indiferenciado (Horn Filho et al., 2014). 
Os maciços rochosos ocorrem em forma de cristas e atravessam a Ilha de Santa Catarina em toda sua extensão, por uma dorsal central orientada, predominantemente, na direção NNE-SSW, as quais se apresentam mais baixas, com altitudes inferiores a 100 m, em direção ao mar onde, geralmente, terminam em pontais rochosos e costões.

A dorsal central é dividida em dois setores. O setor Sul, com $15 \mathrm{~km}$ de comprimento e altitudes que variam de 300 a 532 m no Morro do Ribeirão, e o setor Centro-norte, que abrange as elevações do morro do Campeche ao sul até o morro do Rapa no extremo norte da ilha, sendo o morro da Costa da Lagoa o mais alto com 492 m. Estas duas dorsais são separadas pela planície do Rio Tavares, também denominada de Planície Entremares, constituída por sedimentos quaternários inconsolidados, integrantes do domínio planície costeira (Cruz, 1998; Scheibe, 2002; Almeida, 2004).

Esses maciços cristalinos que afloram na ilha configuraram a formação de diferentes ambientes. A face oeste, mais abrigada e em contato com as águas das baías Norte e Sul, possui elevações suaves com pequenas enseadas e sacos com praias abrigadas, e nas planícies costeiras, drenadas por restritas microbacias que terminam em estuários, se desenvolvem os ambientes de manguezais e marismas. A face leste, por estar em contato direto com o Oceano Atlântico, tem as águas mais agitadas e expostas à ação direta das ondas e dos ventos. A planície é configurada por praias extensas, campos de dunas e cordões arenosos, que isolam lagunas e depressões úmidas, os quais são intercalados por promontórios e costões rochosos (Cruz, 1998).

As praias continentais, por estarem voltadas para baía, apresentam águas calmas e areias mais grossas, com características semelhantes à face oeste da ilha.

\subsection{Procedimentos metodológicos}

O inventário, a primeira etapa de uma estratégia de geoconservação, consiste na identificação e seleção de geossítios e/ou sítios de geodiversidade. Várias metodologias para realização de inventário e avaliação quantitativa foram desenvolvidas nas duas últimas décadas, como por exemplo, Grandgirard (1999), Coratza \& Giusti
(2005), Pralong (2005), Serrano \& González-Trueba (2005), Bruschi \& Cendrero (2005, 2009), Pereira et al. (2007), García-Cortés \& Carcavilla (2009), Pereira \& Pereira (2010), Lima et al. (2010), Reynard \& Coratza (2013), Brilha (2005, 2016).

Neste trabalho, o método utilizado para realizar o inventário foi o de Brilha (2016), que efetivou uma revisão de diferentes métodos e, aliado à sua própria experiência, apresentou uma abordagem sistemática para inventário e métodos de quantificação aplicada a geossítios e sítios de geodiversidade. Diferente dos outros métodos propostos, aquele autor defende que, por haver critérios distintos para os diferentes valores dos sítios (científicos, educacionais, turísticos), a avaliação qualitativa e quantitativa deve ser executada separadamente.

Antes de iniciar o inventário, seus objetivos devem ser claramente definidos a partir de quatro aspectos fundamentais: o tema, o valor, a escala, e o uso (Lima et al., 2010). Para este inventário, o tema corresponde ao patrimônio geológico de Florianópolis, ou seja, os sítios foram selecionados de acordo com seu valor científico, representativos da evolução geológica e geomorfológica de Florianópolis, os quais poderão ser utilizados para promover a geodiversidade local, a educação em geociências e o geoturismo, assim como contribuir com o ordenamento territorial do município e estabelecimento de planos de gestão voltados para a geodiversidade.

De acordo com Brilha (2016), no inventário de geossítios apenas o valor científico (SV) é considerado, sendo que conforme o tamanho da área de trabalho o método será diferente. Este considera área limitada - com menos de 3000-4000 $\mathrm{km}^{2}$ e grandes áreas - com dezenas ou centenas de milhares de quilômetros quadrados.

Devido Florianópolis ter área de $435 \mathrm{~km}^{2}$, o inventário seguiu a sequência de etapas do inventário de áreas limitadas (Quadro 1).

Ao seguir esta sequência, o inventário iniciou com a revisão bibliográfica e cartográfica da área de estudo voltado ao reconhecimento geológico e geomorfológico (mapas geológicos, relatórios, teses, artigos) que permitiram identificar a configuração geológica da área, as categorias temáticas geológicas e potenciais geossítios.

Apesar de no método de inventário de 
áreas limitadas não ser necessária a definição de categorias temáticas, o estabelecimento dessas categorias facilita na organização e identificação de sítios referentes aos principais episódios/momentos chaves na história geológica e/ou geomorfológica do local (Brilha et al., 2005; Pereira et al., 2007; Lima et al., 2010; Brilha, 2016), isso porque as categorias temáticas são definidas a partir da história geológica do território, representam os principais capítulos da história da Terra deixados como evidência na área de estudo (Brilha, 2016). Assim, optou-se por definir categorias temáticas de Florianópolis, segundo os principais episódios da evolução geomorfológica-geológica local (Quadro 2).

Posteriormente, realizou-se uma revisão da literatura geológica, que consistiu na pesquisa em publicações científicas internacionais e nacionais,

Quadro 1. Tarefas sequenciais para inventário de geossítio em áreas limitadas e grandes, levando em consideração apenas o valor científico (SV) (Brilha, 2016, p. 4).

Chart 1. Sequential tasks for geosite inventory in limited and large areas, considering only scientific value (SV) (Brilha, 2016, p 4).

\begin{tabular}{|c|c|}
\hline \multicolumn{2}{|c|}{ GEOSSÍTIO } \\
\hline Inventário de áreas limitadas & Inventário de grandes áreas \\
\hline \multicolumn{2}{|c|}{$\begin{array}{c}\text { Revisão da literatura geológica } \\
\text { Consultorias com especialistas que têm trabalhado na área }\end{array}$} \\
\hline & $\begin{array}{l}\text { Definição das categorias temáticas } \\
\text { geológicas e designação do respectivo } \\
\text { coordenador científico } \\
\text { Caracterização científica de cada } \\
\text { categoria temática } \\
\text { Identificação de geossítios representante } \\
\text { de cada categoria temática geológica }\end{array}$ \\
\hline Lista de potenciais geossítios & $\begin{array}{l}\text { Lista de potenciais geossítios por } \\
\text { categoria temática geológica }\end{array}$ \\
\hline \multicolumn{2}{|c|}{$\begin{array}{l}\text { Trabalho de campo para a identificação de novos geossítios e para a } \\
\text { avaliação qualitativa de cada geossítio da lista de potenciais geossítios, com } \\
\text { base nos quatro critérios seguintes: representatividade, integridade, } \\
\text { raridade e conhecimento científico }\end{array}$} \\
\hline $\begin{array}{l}\text { Lista final dos geossítios com } \\
\text { caracterização total }\end{array}$ & $\begin{array}{c}\text { Lista final dos geossítios por categoria } \\
\text { temática geológica com a caracterização } \\
\text { completa } \\
\end{array}$ \\
\hline
\end{tabular}

Quadro 2. Categorias temáticas de Florianópolis segundo os principais episódios da evolução geomorfológica-geológica local, seguindo a estratigrafia local.

Chart 2. Thematic categories of Florianópolis according to the main episodes of the local geomorphologic-geological evolution, following the local stratigraphy.

\begin{tabular}{|l|c|c|}
\hline \multicolumn{2}{|c|}{ Categoria temática geomorfológica/geológica } & Sigla* \\
\hline \multirow{4}{*}{$\begin{array}{l}\text { Domínio de morros, montanhas e } \\
\text { elevações }\end{array}$} & Enxame de Diques Florianópolis & EDF \\
& Suíte Plutono-Vulcânica Cambirela & SPVC \\
& Granito Ilha & GI \\
& Granito São Pedro de Alcântara & GSPA \\
\hline & Complexo Águas Mornas & CAM \\
\hline \multirow{2}{*}{ Domínio das planícies costeiras } & Depósito de baía & DB \\
& Depósito lagunar praial & DLP \\
& Depósito eólico holocênico & DEH \\
& Depósito flúvio-lagunar & DFL \\
& Depósito paludial & DP \\
& Depósito marinho praial & DMP \\
& Depósito lagunar & DL \\
& Depósito eólico pleistocênico & DEP \\
\hline
\end{tabular}

* Categoria temática 
classificadas até ao estrato B5 pela Coordenação de Aperfeiçoamento de Pessoal de Nível Superior (CAPES), a citação de locais em Florianópolis que contribuíram e/ou são considerados importantes no conhecimento científico geológico. Também foi solicitada a opinião a especialistas, professores de geologia e geomorfologia da Universidade Federal de Santa Catarina (UFSC) e da Universidade do Estado de Santa Catarina (UDESC), que desenvolveram pesquisas na área de estudo. Desta etapa resultou uma lista de 25 potenciais geossítios.

0 próximo passo, o trabalho de campo, teve como objetivos principais reconhecer novos potenciais geossítios e avaliar qualitativamente cada sítio da lista de potenciais geossítios utilizando os seguintes critérios: (i) representatividade: relativa à adequação do geossítio para ilustrar um processo geológico ou recurso, que traz uma contribuição significativa para a compreensão geológica do tema, processo, recurso ou categoria temática geológica; (ii) integridade: relacionadas com o estado atual da conservação do geossítio, tendo em conta os processos naturais e ações humanas; (iii) raridade: abundância de geossítios no município que apresentam características geológicas semelhantes; (iv) conhecimento científico: existência de dados científicos já publicados sobre o geossítio.

Dos 25 potenciais geossítios inicialmente identificados, cinco foram retirados da lista durante o processo de avaliação qualitativa, por não satisfazerem os critérios representatividade e raridade.

Desta etapa resultou uma lista final de 20 geossítios, cada um destes caracterizado através dos seguintes dados propostos por Brilha (2016): (i) nome do geossítio (a fim de facilitar uma rápida e fácil identificação de todos os geossítios, o nome de um geossítio deve incluir o recurso geológico principal e uma referência geográfica); (ii) localização geográfica (incluindo as coordenadas com uso de GPS); (iii) proprietário (público ou privado); (iv) proteção jurídica (se houver); (v) acessibilidade; (vi) fragilidade (referente às alterações nas características físico-químicas do elemento) e vulnerabilidade (referente às ações externas); (vii) categoria geomorfológica-geológica; (viii) tipo de geossítio; (ix) características geológicas notáveis que justificam a necessidade de considerar a ocor- rência como um geossítio; (x) eventuais limitações ao seu uso científico (necessidade de permissão por amostragem, restrições de acesso sazonal, marés, etc.).

\section{Resultados}

A partir do inventário, 20 geossítios foram identificados (Fig. 1) e caracterizados (Quadro 3 e Fig. 2), cuja listagem segue a cronologia geológica local, ou seja, o primeiro geossítio apresentado representa as rochas mais antigas de Florianópolis e último corresponde os depósitos sedimentares mais recentes.

\section{Discussão dos resultados}

Todos os geossítios localizam-se na ilha de Santa Catarina, nove correspondem à categoria geomorfológica-geológica morros, montanhas e elevações e 11 ao domínio da planície costeira (Fig. 2A). Dezessete (17) geossítios possuem algum tipo de proteção jurídica (Fig. 2B), por estarem dentro de áreas protegidas (parques municipais, reserva extrativista ou áreas de preservação permanente), conforme o Plano Diretor de Florianópolis (Florianópolis, 2014). Contudo, algumas áreas poderão vir a ter uma nova classificação com a elaboração do novo plano diretor, ainda em andamento.

Os três geossítios que não apresentam proteção jurídica são: Campo de matacões de granito no morro da Joaquina (10); Paleodunas da praia Mole (11) e Depósitos transicionais do Pântano do Sul (13). Os dois primeiros são classificados no Plano Diretor do mhhhhhhunicípio de Florianópolis como Área de Preservação de Uso Limitado de Encosta (APL-E), ou seja, áreas "que em virtude de suas características de declividade, do tipo de vegetação ou da vulnerabilidade aos fenômenos naturais não apresentam condições adequadas para suportar determinadas formas de uso do solo sem prejuízo do equilíbrio ecológico ou da paisagem natural" (Florianópolis, 2014, p. 16). 0 geossítio Depósitos transicionais do Pântano do Sul está numa Área de Urbanização Especial (AUE), correspondendo a grandes áreas urbanizáveis a partir de projeto amplo, que reserva setor predominante para preservação ambiental e adensa a área rema- 


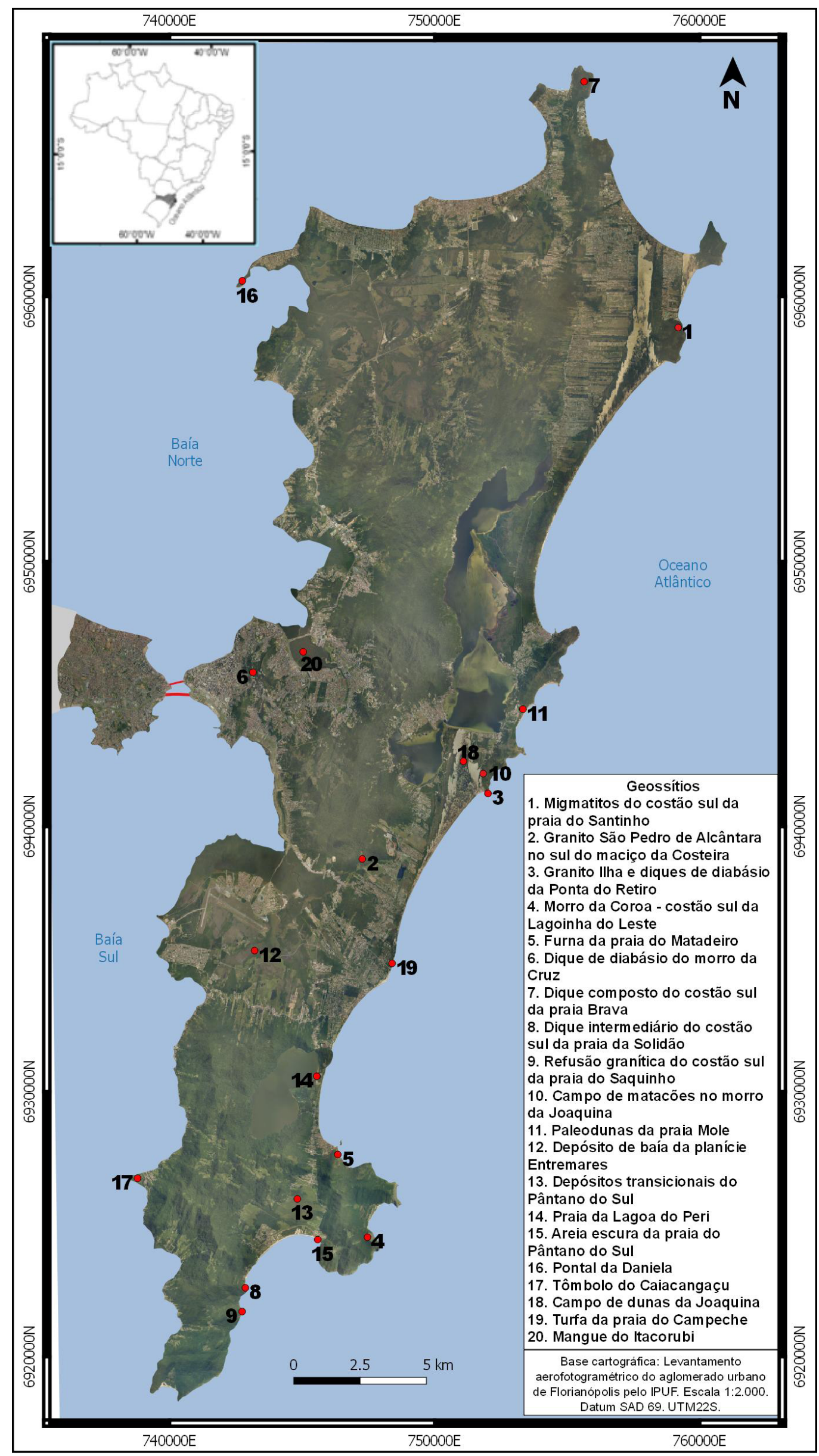

Figura 1. Mapa de localização dos 20 geossítios no Município de Florianópolis.

Figure 1. Map of the location of the 20 geosites in the Municipality of Florianópolis. 
Quadro 3. Dados principais de caracterização dos geossítios no município de Florianópolis.

Chart 3. Main characterization data for geosites in the municipality of Florianópolis.

\begin{tabular}{|c|c|c|c|c|c|}
\hline Geossítio & \begin{tabular}{|l|}
$\begin{array}{l}\text { Categoria } \\
\text { temática* }\end{array}$ \\
\end{tabular} & $\begin{array}{l}\text { Proteção } \\
\text { jurídica }\end{array}$ & \begin{tabular}{|c|}
$\begin{array}{c}\text { Acessibilid } \\
\text { ade }\end{array}$ \\
\end{tabular} & $\begin{array}{c}\text { Fragilidade/ } \\
\text { vulnerabilidade }\end{array}$ & \begin{tabular}{|c} 
Qualis* \\
$*$ \\
\end{tabular} \\
\hline $\begin{array}{l}\text { 1. Migmatitos do costão sul } \\
\text { da praia do Santinho }\end{array}$ & CAM & APP & Fácil & - & - \\
\hline $\begin{array}{l}\text { 2. Granito São Pedro de } \\
\text { Alcântara no sul do maciço } \\
\text { da Costeira }\end{array}$ & GSPA & $\begin{array}{c}\text { Parque } \\
\text { municipal }\end{array}$ & Médio & - & - \\
\hline $\begin{array}{l}\text { 3. Granito Ilha e diques de } \\
\text { diabásio na ponta do Retiro }\end{array}$ & $\begin{array}{c}\mathrm{GI} \\
\mathrm{EDF}\end{array}$ & APP & Fácil & - & A1 \\
\hline $\begin{array}{l}\text { 4. Morro da Coroa - costão } \\
\text { sul da Lagoinha do Leste }\end{array}$ & SPVC & $\begin{array}{c}\text { Parque } \\
\text { municipal }\end{array}$ & Médio & $\begin{array}{c}\text { Erosão na trilha } \\
\text { de acesso }\end{array}$ & A1 \\
\hline $\begin{array}{l}\text { 5. Furna da praia do } \\
\text { Matadeiro }\end{array}$ & $\begin{array}{l}\text { SPVC } \\
\text { EDF }\end{array}$ & APP & Fácil & Depredação & B5 \\
\hline $\begin{array}{l}\text { 6. Dique de diabásio do } \\
\text { morro da Cruz }\end{array}$ & EDF & $\begin{array}{c}\text { Parque } \\
\text { municipal }\end{array}$ & Médio & $\begin{array}{c}\text { Ocupação } \\
\text { urbana }\end{array}$ & A2 \\
\hline $\begin{array}{l}\text { 7. Dique composto do } \\
\text { costão sul da praia Brava }\end{array}$ & EDF & APP & Médio & - & B2 \\
\hline $\begin{array}{l}\text { 8. Dique intermediário do } \\
\text { costão sul da praia da } \\
\text { Solidão }\end{array}$ & EDF & APP & Médio & - & A2 \\
\hline $\begin{array}{l}\text { 9. Refusão granítica do } \\
\text { costão sul da praia do } \\
\text { Saquinho }\end{array}$ & EDF & APP & Médio & - & A2 \\
\hline $\begin{array}{l}\text { 10. Campo de matacões de } \\
\text { granito no morro da } \\
\text { Joaquina }\end{array}$ & DCA & - & Fácil & $\begin{array}{c}\text { Ocupação } \\
\text { urbana }\end{array}$ & - \\
\hline $\begin{array}{l}\text { 11. Paleodunas da praia } \\
\text { Mole }\end{array}$ & $\overline{\mathrm{DEP}}$ & - & Fácil & $\begin{array}{c}\text { Ocupação } \\
\text { urbano-turística }\end{array}$ & B2-B3 \\
\hline $\begin{array}{l}\text { 12. Depósito de baía da } \\
\text { Planície Entremares }\end{array}$ & $\overline{\mathrm{DB}}$ & $\begin{array}{c}\text { Reserva } \\
\text { extrativista }\end{array}$ & Fácil & - & B5 \\
\hline $\begin{array}{l}\text { 13. Depósitos transicionais } \\
\text { do Pântano do Sul }\end{array}$ & $\begin{array}{l}\text { DL } \\
\text { DFL }\end{array}$ & cacturivivec & Fácil & $\begin{array}{c}\text { Ocupação } \\
\text { urbana }\end{array}$ & - \\
\hline 14. Praia da Lagoa do Peri & DLP & $\begin{array}{c}\text { Parque } \\
\text { municipal }\end{array}$ & Fácil & - & - \\
\hline $\begin{array}{l}\text { 15. Areia escura da praia do } \\
\text { Pântano do Sul }\end{array}$ & DMP & APP & Fácil & $\begin{array}{c}\text { Ocupação } \\
\text { urbana }\end{array}$ & B2-B5 \\
\hline 16. Pontal da Daniela & $\overline{D M P}$ & $\begin{array}{c}\text { Estação } \\
\text { ecológica }\end{array}$ & Fácil & - & A1 \\
\hline $\begin{array}{l}\text { 17. Tômbolo do } \\
\text { Caiacangaçu }\end{array}$ & $\overline{D M P}$ & APP & Fácil & - & B1 \\
\hline $\begin{array}{l}\text { 18. Campo de dunas da } \\
\text { Joaquina }\end{array}$ & $\overline{\mathrm{DEH}}$ & $\begin{array}{c}\text { Parque } \\
\text { municipal }\end{array}$ & Fácil & - & A1 \\
\hline $\begin{array}{l}\text { 19. Turfa da praia do } \\
\text { Campeche }\end{array}$ & $\overline{\mathrm{DP}}$ & APP & Fácil & $\begin{array}{l}\text { Ocultação do } \\
\text { afloramento }\end{array}$ & - \\
\hline 20. Mangue do Itacorubi & $\overline{\mathrm{DP}}$ & $\begin{array}{c}\text { Parque } \\
\text { municipal }\end{array}$ & Fácil & - & $\mathrm{A} 1$ \\
\hline
\end{tabular}

* Vide quadro 2 ;

** Qualificação CAPES das publicações relativas aos geossítios;

APP = Área de Preservação Permanente. 


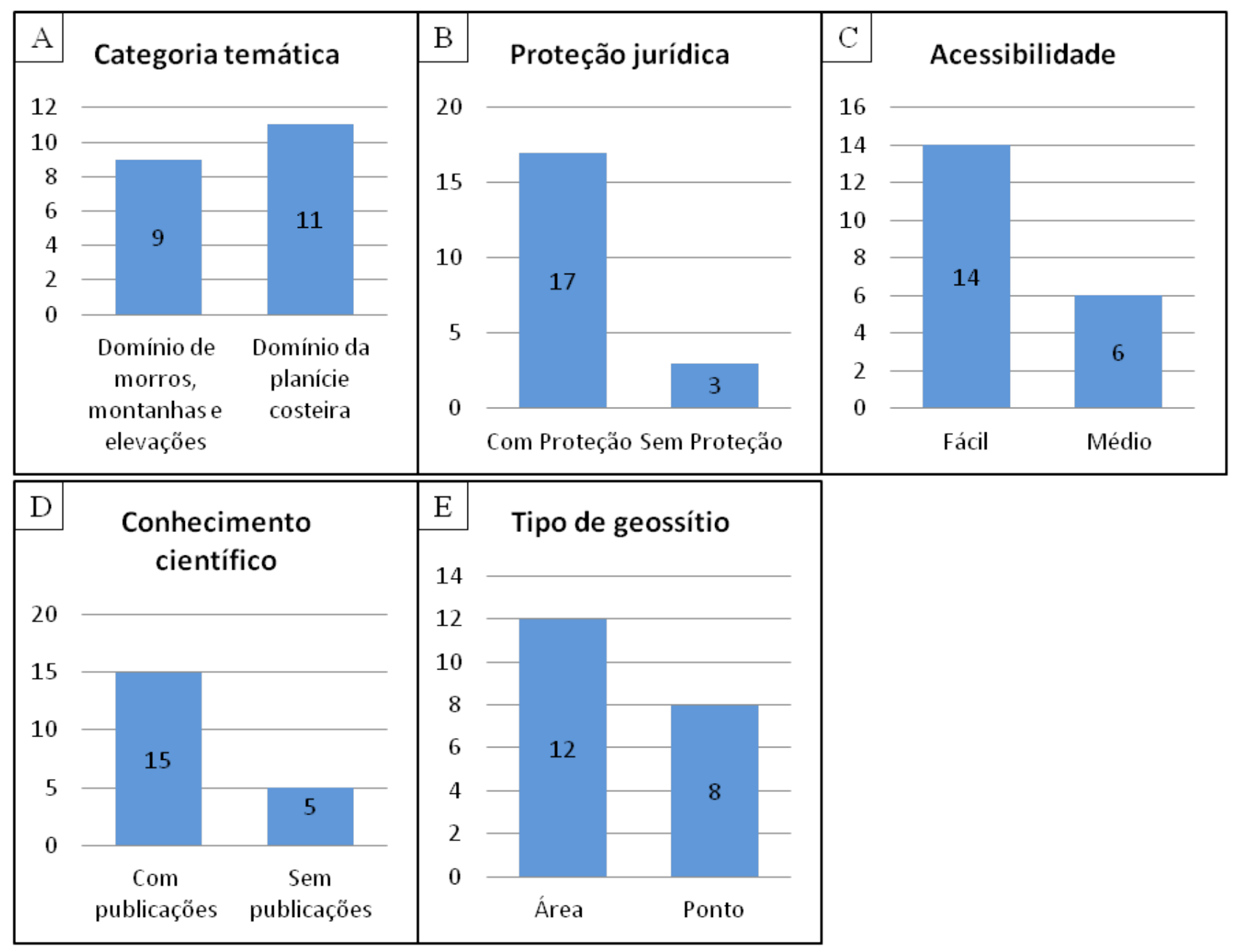

Figura 2. Gráficos dos principais dados de caracterização dos geossítios. A) Número de geossítios em cada categoria temática; B) Número de geossítios com ou sem proteção jurídica; C) Número de geossítios com acessibilidade fácil ou média; D) Número de geossítios com e sem publicação científica; E) Tipologia de geossítios.

Figure 2. Graphics of the main characterization data of geosites. A) Number of geosites in each framework; B) Number of geosites with or without legal protection, C) Number of geosites with easy or medium accessibility; D) Number of geosites with and without scientific publication; E) Type of geosites.

nescente, e numa ALA-2, Área de Limitação Ambiental passíveis de inundação. Logo, esses sítios estão em áreas que possuem algum tipo de proteção, mas onde é permitida a construção de edificações.

Portanto, identificou-se o crescimento urbano-turístico como principal vulnerabilidade dos geossítios, independentemente da proteção jurídica que possuem. 0 limite urbano muitas vezes faz fronteira com as áreas protegidas, as quais têm seus territórios delimitados apenas em mapas. Logo, progressivamente a expansão urbana acaba por ultrapassar estes limites devido à falta de fiscalização ambiental ou mesmo com a autorização dos órgãos ambientais.

Outro problema é a inexistência de plano de manejo nas unidades de conservação, que aca- bam sendo utilizadas para atividades desportivas e trilhas pedestres sem nenhum tipo de controle ou sinalização. Das unidades de conservação de Florianópolis, apenas o Parque Natural Municipal do Morro da Cruz, onde está o geossítio Dique de diabásio do morro da Cruz (6), a Estação Ecológica de Carijós onde situa-se o geossítio Pontal da Daniela (16), possuem plano de manejo concluído.

Em alguns geossítios com proteção legal, como na Furna da praia do Matadeiro (5), Granito Ilha e Diques de Diabásio na ponta do Retiro (3) e Turfa da praia do Campeche (19), que estão em APP, foram observadas ações de depredação e intervenção humana que os põem em risco, como pichação nas rochas (Fig. 3A) e criação de rampa de acesso de veículos à praia sobre o afloramento de turfa (Fig. 3B). Entretanto, não foi constatada 
nenhuma fragilidade intrínseca nos geossítios selecionados.

Em relação à acessibilidade (Fig. 2C), 14 geossítios apresentam fácil acesso, por meio de veículo ou trilhas curtas. Os seis sítios que possuem acesso de nível médio, apresentam trilhas mais longas de 30-60 min. de caminhada, mas sem muitos obstáculos. Em alguns locais a área de estacionamento deve ser estabelecida ou delimitada, para evitar que os veículos estacionem em áreas impróprias, como acontece no geossítio Campo de dunas da Joaquina (18), onde os veículos estacionam sobre as dunas.

Os geossítios que possuem acesso por meio de trilhas longas devem ter a respetiva capacidade de carga analisada, para estabelecer ações que possam minimizar o impacto sobre estas. $\mathrm{Na}$ trilha de acesso ao geossítio Morro da Coroa (4) costão sul da Lagoinha do Leste, a partir da praia da Lagoinha do Leste, é visível o processo erosivo (Fig. 4A) que vem sendo ocasionado em decorrência da alta declividade e da vegetação rasteira que é eliminada através do pisoteio e que acaba por ex- por o solo (Fig. 4B), provocando o aparecimento de ravinas em vários pontos do percurso.

Quinze geossítios são citados em publicações científicas classificadas até ao estrato B5 pela CAPES, fato que enfatiza ainda mais a sua importância científica. Existem cinco geossítios que não deram ainda origem a publicações, embora não tenha sido descartado o seu valor científico neste inventário (Fig. 2D). De acordo com o tipo de geossítio (Fig. 2E), 12 são tipo áreas, com apenas um tipo de interesse, e oito são do tipo ponto, pequenas áreas de até 1ha (Fuertes-Guitiérrez \& Fernández-Martinez, 2010).

Os geossítios tipo ponto geralmente são mais vulneráveis a ações externas em razão de sua dimensão e podem ser facilmente popularizados por meios de painéis de interpretação, como por exemplo, a Furna da praia do Matadeiro (5). Os geossítios de tipo área devem ter sua extensão delimitada. Estes, por terem maior porte, possuem fragilidade e vulnerabilidade baixa, logo, suportam uma pressão mais elevada. Como exemplo de geossítios tipo área tem-se o Mangue do Itacorubi (20)

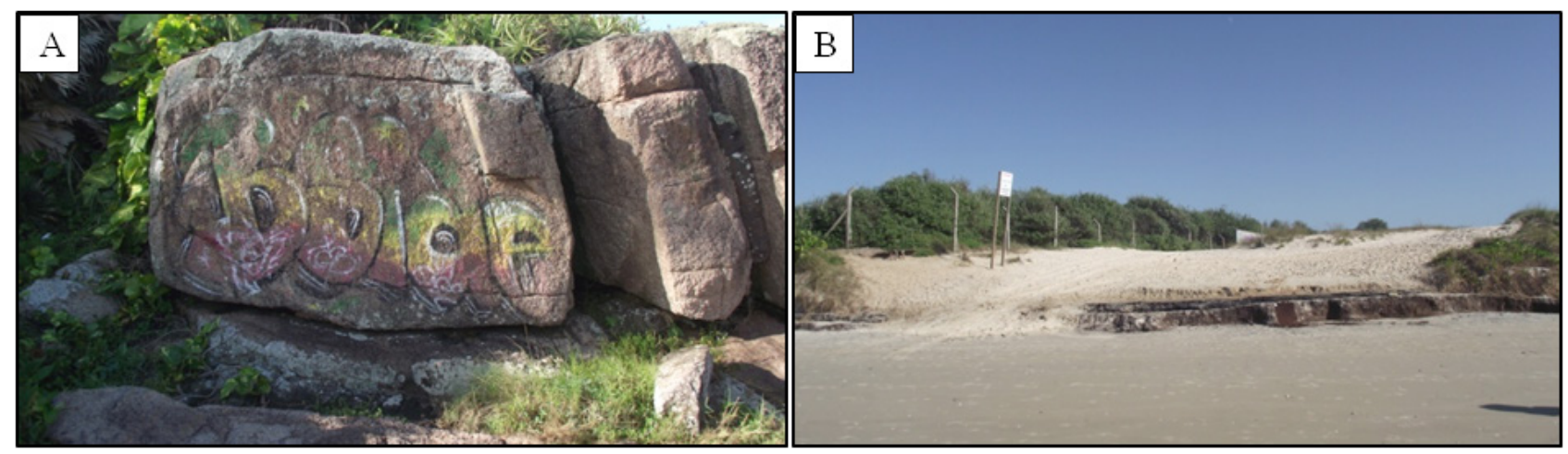

Figura 3. Depredações observadas nos geossítios. A) Pichação no Granito Ilha na ponta do Retiro; B) Rampa de areia que encobre parte do afloramento de Turfa da praia do Campeche.

Figure 3. Depredations observed in geosites. A) Graffiti on the Granite Ilha at the ponta do Retiro; B) Sand ramp that covers part of the peat outcrop of Campeche beach.
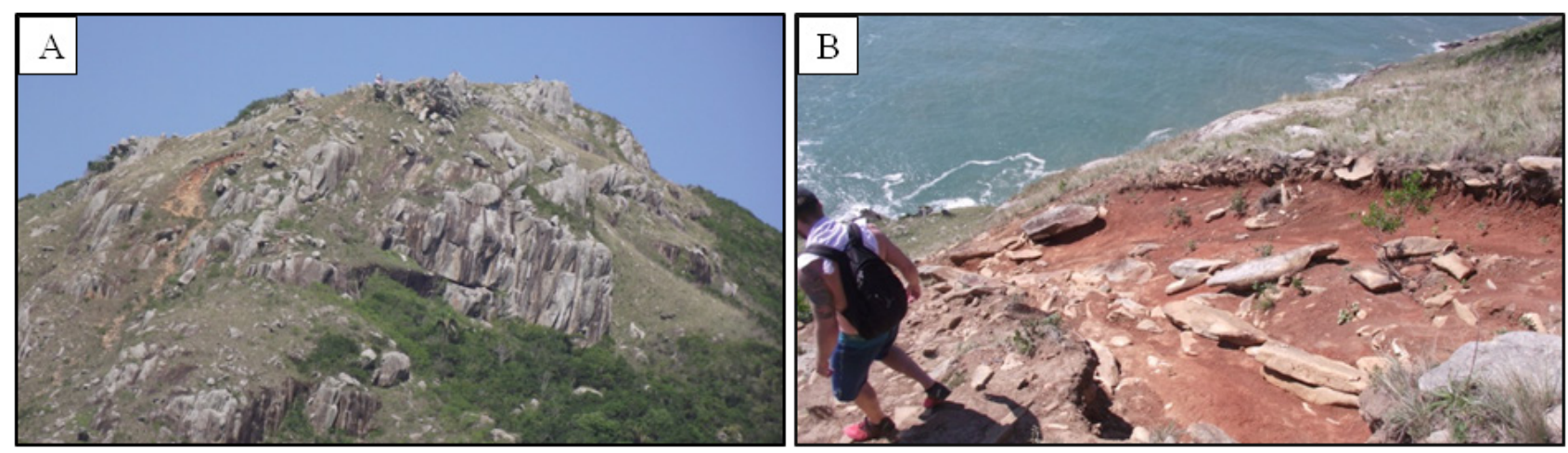

Figura 4. Processo erosivo na trilha do geossítio Morro da Coroa - costão sul da Lagoinha do Leste. A) Topo do Morro da Coroa com cicatriz visível causada por uma ravina; B) Ravina na trilha do Morro da Coroa.

Figure 4. Erosive process on the trail of the Coroa Hill geosite - southern cliff of Lagoinha do Leste. A) Top of Coroa Hill with visible scar caused by a ravine; B) Ravine on the trail of the Coroa Hill. 
e Praia da Lagoa do Peri (14).

As características geológicas que justificam o valor científico de cada um dos 20 geossítios são apresentadas de modo breve.

\subsection{Migmatitos do Costão Sul da praia do Santinho (CAM)}

Localizado entre as praias do Santinho e do Moçambique, na costa Nordeste da Ilha de Santa Catarina, exibe as rochas mais antigas da ilha, que correspondem ao Complexo Águas Mornas (CAM). 0 complexo é constituído por ortognaisses e migmatitos (Fig. 5A e B), cujas datações $\mathrm{UPb}$
SHRIMP indicaram idade de $2.175 \pm 13$ Ma AP para o protólito e $592 \pm 5$ Ma AP para o metamorfismo/ deformação superimpostos (Silva et al., 2000). Apresentam-se envoltos por granitos remobilizados, equigranulares, finos a médios, de cor rosada, que constituem uma rede de veios e bandas de espessura variada. Representam restos de uma sequência mais antiga, deformada e metamorfisada, intrudida por rochas graníticas (Tomazzoli e Pellerin, 2015). 0 costão também possui outros elementos geológicos como, processos de alteração das rochas, diques, furna de abrasão marinha, assim como elementos arqueológicos, nomeadamente oficinas líticas e gravuras rupestres.

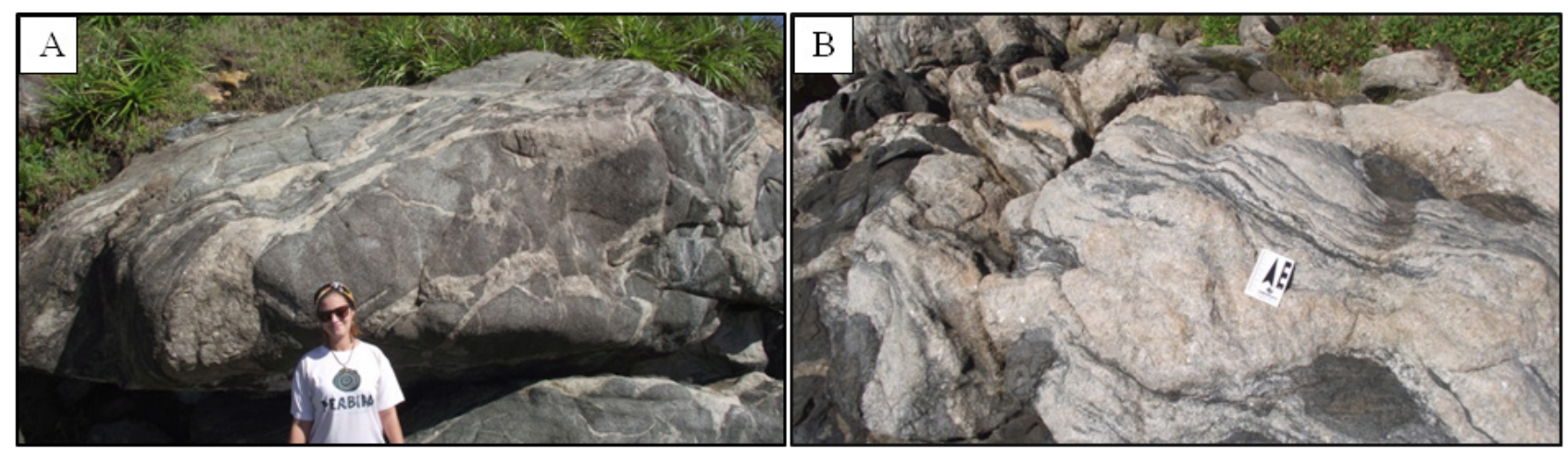

Figura 5. Geossítio Migmatitos do Costão Sul da praia do Santinho. A) Brechação de anfibolitos por net-veining de remobilizados graníticos rosados; B) Migmatito bandado, com bandas de remobilizado granítico rosado, intercaladas a bandas de anfibolitos parcialmente assimilados e enclaves máficos.

Figure 5. Geosites Migmatitos of the South Coast of Santinho beach. A) Brecciation of amphibolites by net-veining of pink granite; B) Banded migmatite with bands of pink granitic, interspersed with bands of partially assimilated amphibolites and mafic enclaves.

\subsection{Granito São Pedro de Alcântara no sul do Maciço da Costeira (GSPA)}

Constituído por granitoides calcialcalinos, como monzogranito (predominante), sienogranito e quartzo-monzonito, integrantes da Suíte Maruim, intrusiva no Complexo Águas Mornas (Zanini et al., 1997). 0 Granito São Pedro de Alcântara (GSPA) ocorre apenas no sul do maciço da Costeira, bairro Rio Tavares, e seu afloramento é de difícil visualização (Fig. 6A, B e C). Apresenta coloração cinza, granulação grossa a média, com fenocristais brancos de feldspato potássico e abundantes enclaves de andesito, diorito, tonalito ou granodiorito. Datações pelos métodos $\mathrm{Rb}-\mathrm{Sr}$ e U-Pb indicaram idades isocrônicas de, respectivamente, $566 \pm 93 \mathrm{Ma}$ e $600 \pm 7$ Ma (Tomazzoli \& Pellerin, 2014, 2015).

4.3 Granito Ilha e diques de diabásio da ponta do Retiro (GI e EDF)
Na ponta do Retiro, localizada no maciço costeiro do setor Centro-leste da Ilha de Santa Catarina, ao norte da praia da Joaquina, afloram diques de diabásio do Enxame de Diques Florianópolis (EDF), intrudidos em rochas cristalinas do Granito Ilha (GI) do Proterozoico superior.

O Granito Ilha (Fig. 7A) é a unidade litoestratigráfica integrante da Suíte Pedras Grandes que constitui a maior parcela de rochas aflorantes no município de Florianópolis, em contato com todas as demais litologias, presentes tanto nos maciços do setor Sul e Centro-norte, bem como em toda a parte continental, diversos promontórios e ilhas costeiras próximas. É uma rocha intrusiva, de textura equigranular, granulação média a grossa, coloração cinza a rósea, isótropa, possuindo deformação cataclástica. Podem gradar entre termos monzograníticos, sienograníticos e, subordinadamente, quartzo-monzonitos e quartzo-sienitos (Caruso Jr., 1993; Zanini et al., 1997). 
Os diabásios verticais e subverticais (Fig. 7B) apresentam orientação dominante NE e secundária NW, correspondendo às direções estruturais do embasamento cristalino na Ilha de Santa Catarina, cujos contatos geológicos são visíveis no afloramento da ponta do Retiro. Estudo paleomagnético e geocronológico realizado por Raposo et al. (1998) mostrou diques de polaridade normal NW, cortando diques de polaridade inversa NE, bem como duas modas de idades inferidas pelo 40Ar/39Ar, importando em 128-126 Ma AP e 122119 Ma AP, correspondendo ao Cretáceo.
4.4 Morro da Coroa - costão sul da Lagoinha do Leste (SPVC)

Elevação na forma de morro do maciço costeiro do setor Sudeste da Ilha de Santa Catarina, formada por materiais piroclásticos (ignimbritos) e lavas ácidas (riolitos e riolitos pórfiros) da Suíte Plutono-Vulcânica Cambirela (SPVC). Em alguns locais, estas rochas exibem grande concentração de lapillis e bombas, com formas arredondadas, elipsóidicas ou retorcidas. No relevo, a característica marcante é a presença de blocos residuais expostos por processos erosivos, os quais perma-

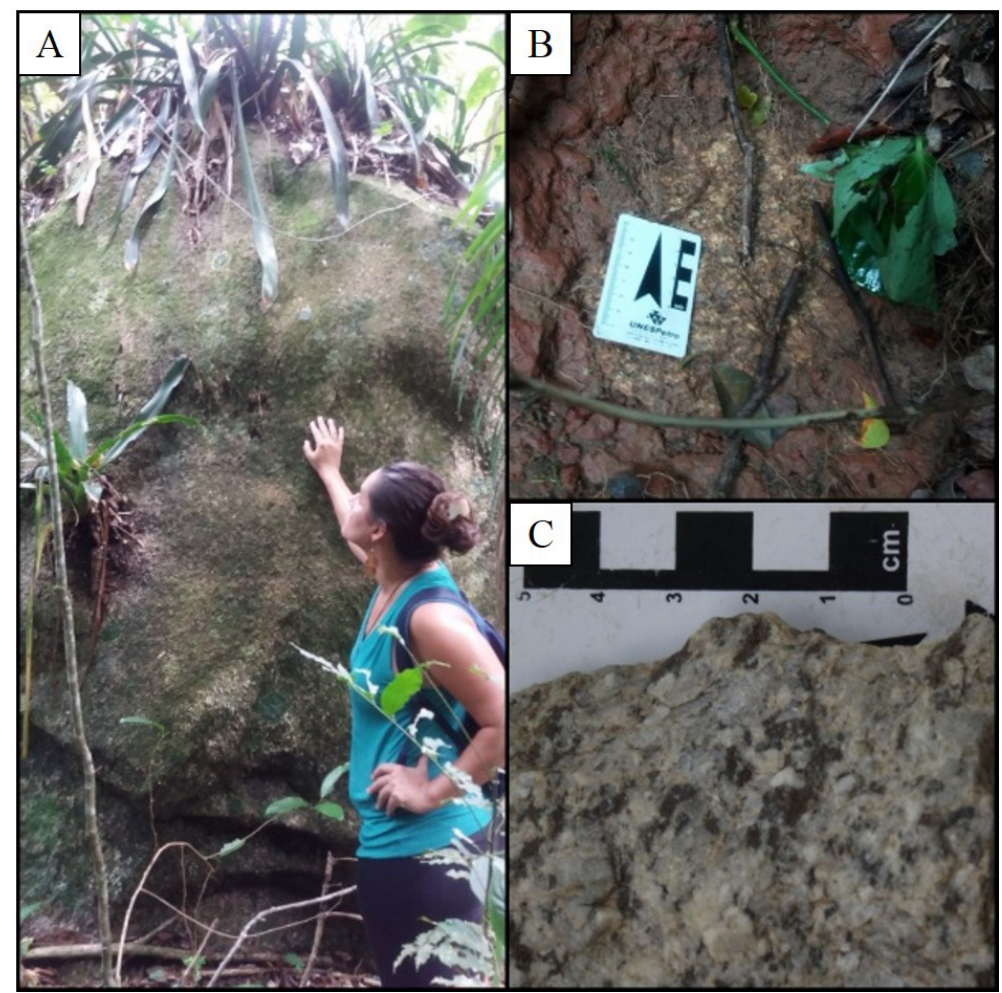

Figura 6. Geossítio Granito São Pedro de Alcântara. A) Matacão de Granito São Pedro de Alcântara; b) Cascalho de Granito São Pedro de Alcântara em meio a trilha; C) Detalhe do Granito São Pedro de Alcântara com fenocristais brancos de feldspato potássico.

Figure 6. Geosite Granito São Pedro de Alcântara. A) Boulder Granite São Pedro de Alcântara; b) Granite gravel São Pedro de Alcântara in the middle of the trail; C) Detail of the São Pedro de Alcântara granite with white phenocrystal of potassic feldspar.
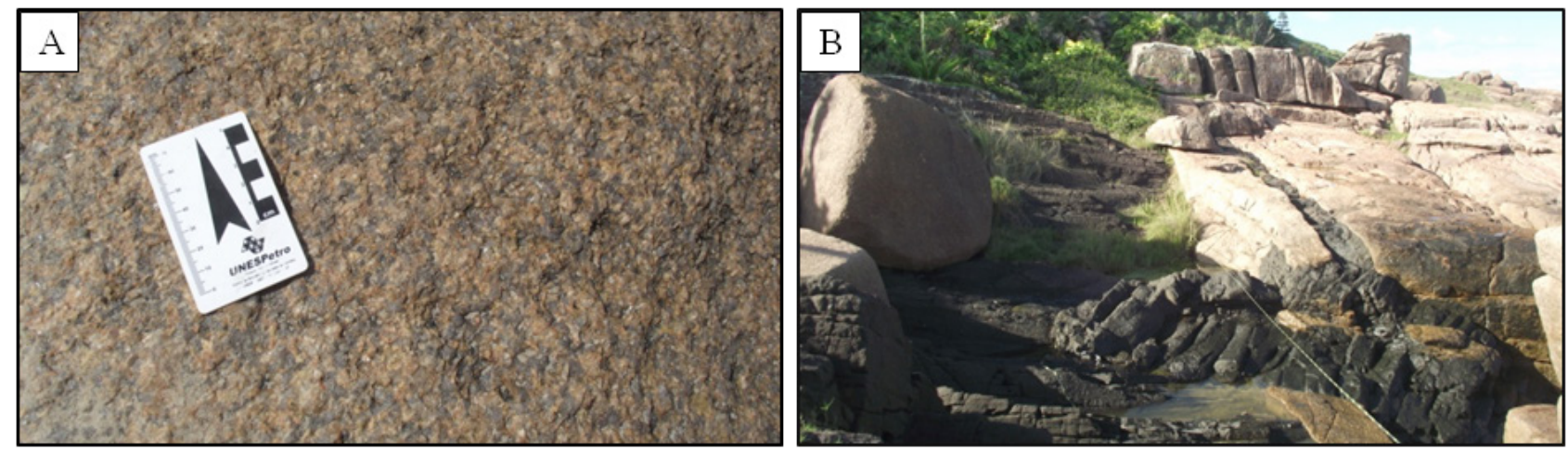

Figura 7. Geossítio Granito Ilha e diques de diabásio da ponta do Retiro. A) Aspecto macroscópico do Granito Ilha; B) Cruzamento de diques de diabásio na ponta do Retiro.

Figure 7. Geosite Granite Ilha and diabase dikes of ponta do Retiro. A) General naked eye aspect of Granite Ilha; B) Crossing of diabase dikes at the ponta do Retiro. 
necem no local. Esses blocos ocorrem nos maciços que circundam a praia da Lagoinha do Leste, com destaque ao morro da Coroa. No afloramento as rochas aparecem em forma de lajes pontiagudas verticais, horizontais e tangenciais, lembrando a forma de uma coroa real, por isso a denominação de morro da Coroa (Fig. 8A e B).

\subsection{Furna da praia do Matadeiro (SPVC e EDF)}

Furna de abrasão marinha (Fig. 9A) em rochas piroclásticas ácidas (SPVC), ao longo de planos de fraqueza representados por fraturas que perpassam longitudinalmente um dique de diabásio com mais de $10 \mathrm{~m}$ de espessura (EDF). No interior, ocorre coquina biogênica com a presença de restos de conchas parcialmente dissolvidas, cimentando seixos arredondados e fragmentos angulosos de diabásio (Fig. 9B), além de sedimentos de tamanho grânulo e areia (Tomazzoli et al., 2012).

\subsection{Dique de diabásio do Morro da Cruz (EDF)}

Representa o maior dique de diabásio (EDF) do município de Florianópolis, que chega a atingir espessura de $200 \mathrm{~m}$. Apresenta nas bordas granulação fina (Fig. 10A), afanítica, que grada para granulação grossa no centro do dique (Fig. 10B), com cristais de plagioclásio e piroxênio atingindo $5 \mathrm{~mm}$ de diâmetro (Tomazzoli \& Pellerin, 2015).

\subsection{Dique composto do Costão sul da praia Brava (EDF)}

Dique de riolito-dacito toleítico pertencente ao Enxame de Diques Florianópolis (EDF). Trata-se de um dique composto, com bordas de diabásio e centro de riolito-dacito (Fig. 11A e B). Possui orientação $\mathrm{N} 50^{\circ} \mathrm{E}$, largura média de $45 \mathrm{~m}$ e fraturas perpendiculares à sua direção (fraturas de resfriamento) (Pellerin et al., 2010).

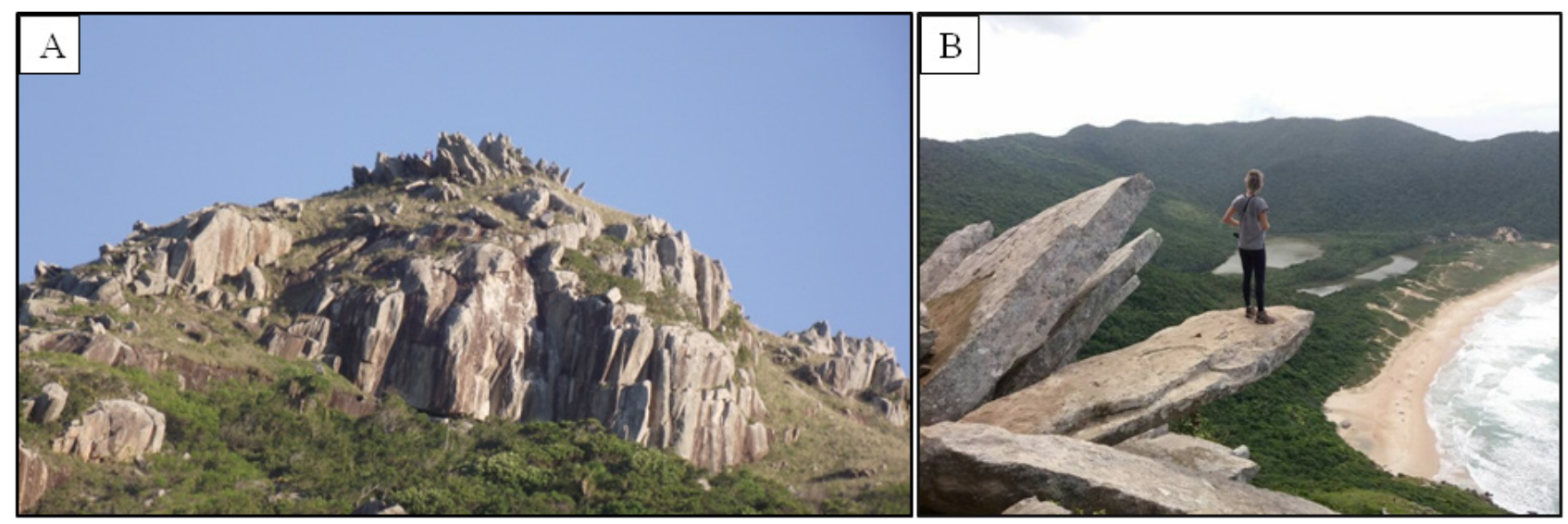

Figura 8. Geossítio Morro da Coroa - costão sul da Lagoinha do Leste. A) Topo do morro da Coroa, formado por lajes pontiagudas verticais, horizontais e inclinadas; B) Lajes pontiagudas que compõe a coroa.

Figure 8. Geosite Coroa Hill - southern cliff of Lagoinha do Leste. A) Top of Coroa Hill, formed by vertical, horizontal and sloping pointed slabs; B) Pointed slabs making up the crown.
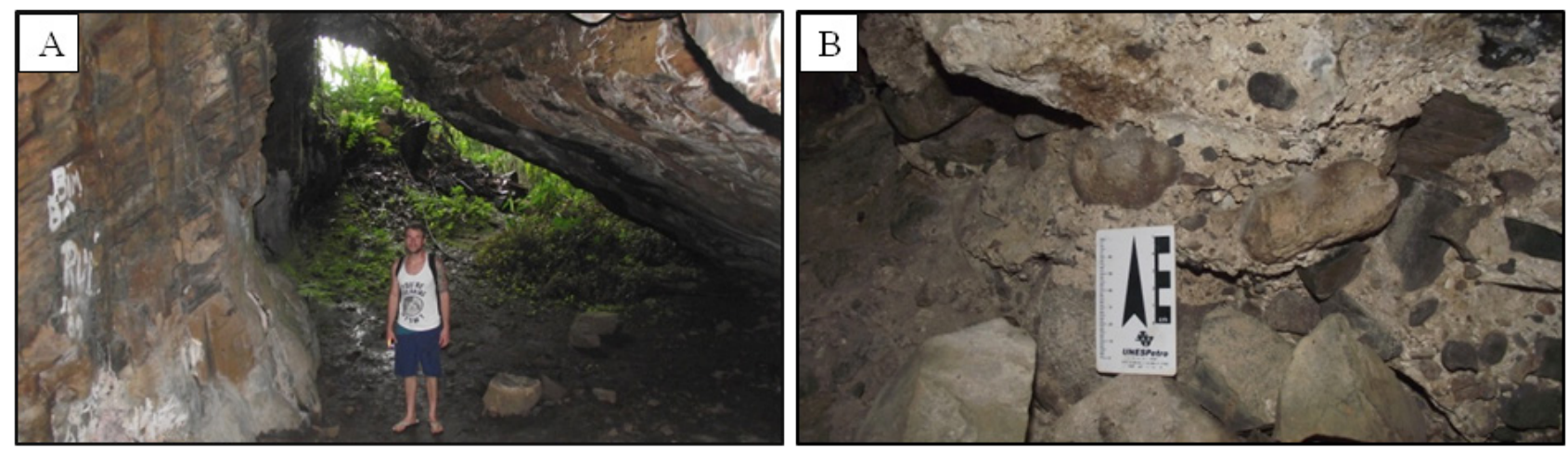

Figura 9. Geossítio Furna da praia do Matadeiro. A) Furna de abrasão marinha da praia do Matadeiro, com pichação em sua parede à esquerda da foto; B) Coquina biogênica cimentando seixo e fragmentos angulosos.

Figure 9. Geosite Furna of Matadeiro beach. A) Furna of marine abrasion from Matadeiro beach, with graffiti on its wall to the left of the photo; B) Biogenic coquina cementing pebble and angular fragments. 

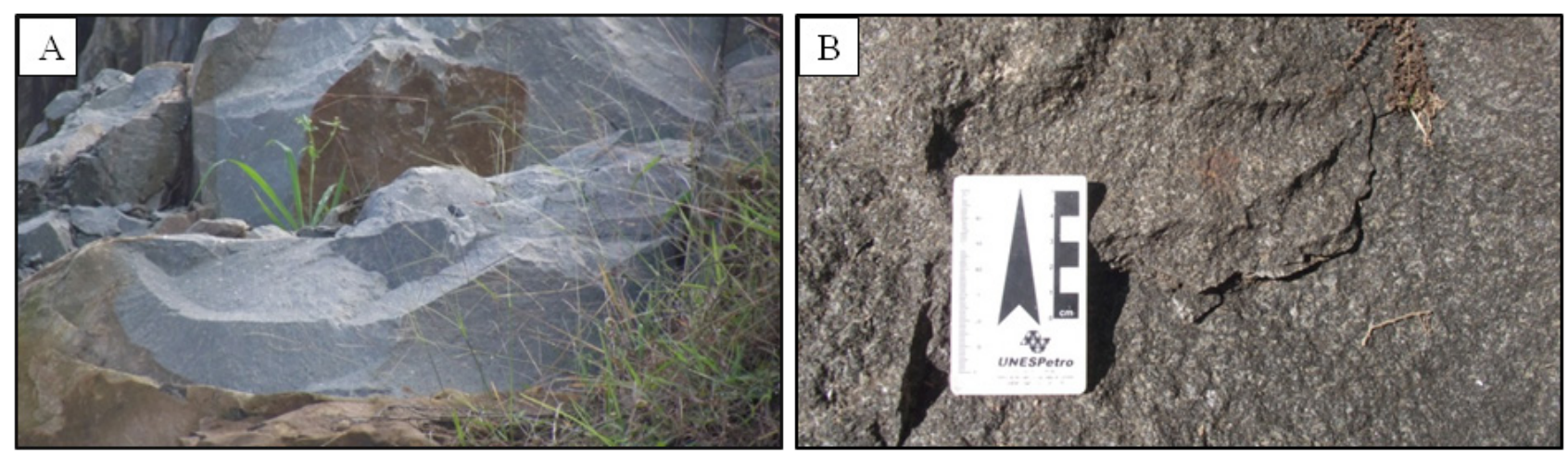

Figura 10. Geossítio Dique de diabásio do morro da Cruz. A) Borda do dique de diabásio apresentando granulação fina; B) Centro do dique evidenciando granulação grossa.

Figure 10. Geosite Diabase dike of the hill of Cruz. A) Edge of the diabase dike presenting fine granulation; B) Center of the dike showing coarse-grained minerals.

\subsection{Dique intermediário do Costão sul da praia da Solidão (EDF)}

Dique simples ou composto com bordas de andesito basáltico e núcleo de traquiandesito (Fig. $12 \mathrm{~A}$ e B) contendo enxames de enclaves máficos magmáticos do andesito basáltico da borda (EDF). Os diques compostos representam uma evidente interação no estágio magmático entre as rochas do seu núcleo e borda (Tomazzoli \& Pellerin, 2015).

\subsection{Refusão granítica do Costão sul da praia do Sa- quinho (EDF)}

Espesso dique de diabásio (EDF) que expõe bordas curvilíneas, irregulares e por vezes transicionais ao Granito Ilha encaixante (Fig. 13A); exibe numerosos enclaves máficos magmáticos do dique (Fig. 13B), indicando processo de magma mingling entre elas (Tomazzoli \& Pellerin, 2015).
4.10 Campo de matacões de granito no Morro da Joaquina (DCA)

Depósito coluvial (DCA) no sopé do morro da Joaquina (Fig. 14A e B), situado em frente ao campo de dunas da Joaquina, onde afloram matacões de Granito Ilha provenientes de processos intempéricos que agiram sobre o embasamento cristalino e transportados pela ação de fluxos gravitacionais.

\subsection{Paleodunas da praia Mole (DEP)}

Rampa arenosa ou rampa de dissipação caracterizada por desenvolver uma feição geomorfológica eólica condicionada por um obstáculo topográfico (Fig. 15A e B). 0 Depósito eólico (DEP) na praia Mole representa uma extensa área, a qual, conforme Paisani (2007), foi formada durante o último glacial, a partir de fase regressiva do penúltimo máximo transgressivo e exibe sete camadas
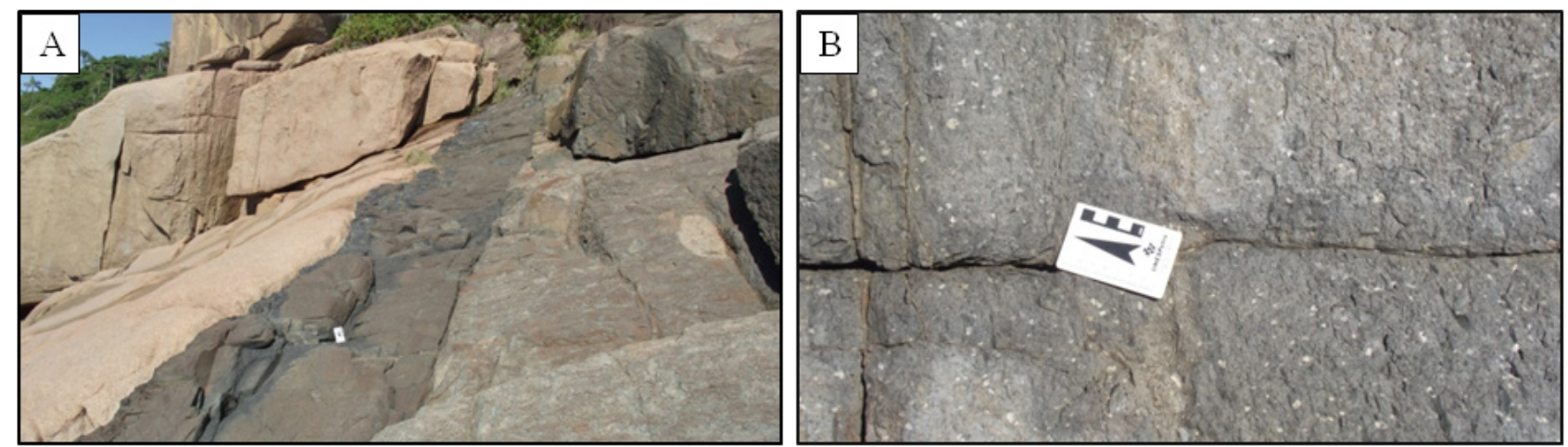

Figura 11. Geossítio Dique composto do Costão sul da praia Brava. A) Contato do Granito Ilha, à esquerda, com a borda de diabásio, no meio, e o riolito-dacito, à direita; B) Riolito-dacito com fenocristais de plagioclásio, numa matriz afanítica marrom-clara. Figure 11. Geosite Dick composed of the south coast of the Brava beach. A) Contact of the Granite Ilha, to the left, with the diabase border in the middle, and the rhyolite-dacite, to the right; B) Rhyolite-dacite with plagioclase phenocrysts, in a pale brown aphanitic matrix. 

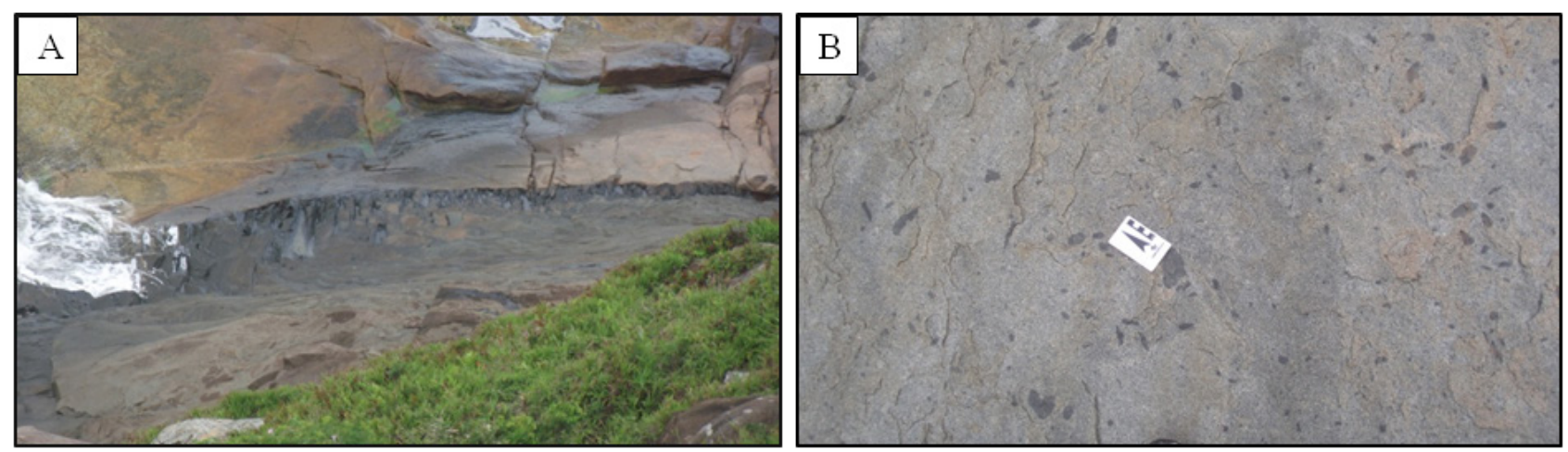

Figura 12. Geossítio Dique intermediário do Costão sul da praia da Solidão. A) Contato entre Granito Ilha, a borda de andesito basáltico e o núcleo de traquiandesito; B) Traquiandesito com enxame de enclaves máficos magmáticos do andesito basáltico da borda.

Figure 12. Geosite Intermediate dick of the south coast of the Solidão beach A) Contact between Granite Ilha, the border of basaltic andesite and the traquiandesito core; B) Traquiandesito with swarm of magmatic mafic enclaves of basaltic andesite of the border.
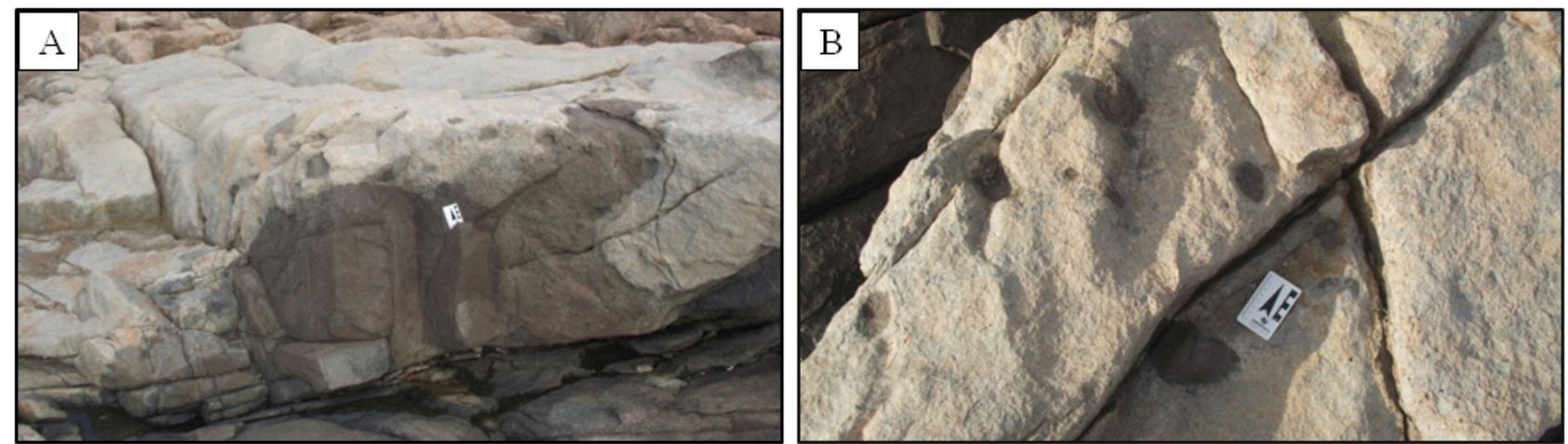

Figura 13. Geossítio Refusão granítica do Costão sul da praia do Saquinho. A) Dique de diabásio com bordas curvilíneas, irregulares e transicionais ao granito encaixante; B) Enclaves máficos magmáticos do dique, indicando processos de magma mingling entre elas.

Figure 13. Geosite Refusion granitic of the south Coast of the Saquinho beach. A) Diabase dike with curved edges, irregular and transitional enclosing the granite; B) Magmatic mafic enclaves of the dyke, indicating magma mingling between them.
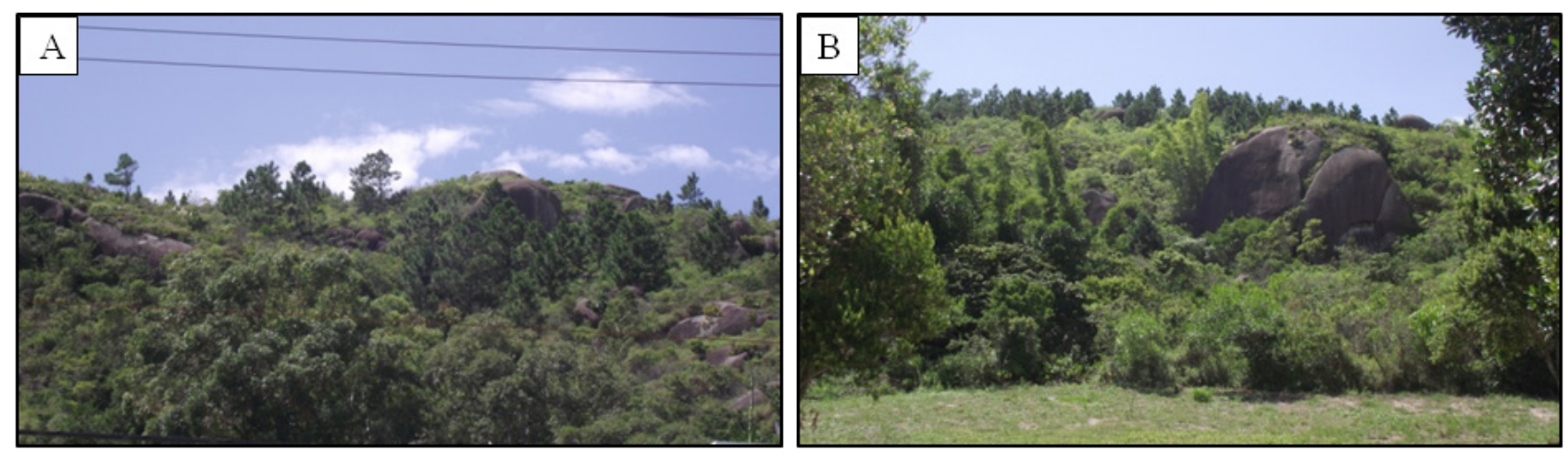

Figura 14. Geossítio Campo de matacões de granito no morro da Joaquina. A e B) Matacões de diferentes tamanhos em meio a vegetação no morro da Joaquina.

Figure 14. Geosite Field of granite boulders on the Joaquina hill. A e B) Boulder of different sizes in the middle of the vegetation in Joaquina hill.

eólicas e cinco camadas de dissipação, cujas últimas são mais delgadas. Este autor, por meio da caracterização sedimentológica de seções colunares, individualizou 19 camadas que se dividem em quatro litofácies: tecnogênica, eólica, de dissipação e praial, bem como três paleossolos.

\subsection{Depósito de baía da Planície Entremares (DB)}

Segundo Almeida (2004), a Planície Entremares limita a descontinuidade dos maciços dos setores Sul e Centro-norte da Ilha de Santa Catarina, que durante o máximo transgressivo do Pleistoceno superior, deveria estar situada 
a $8 \pm 2 \mathrm{~m}$ acima do atual há cerca de $120 \mathrm{Ka}$ AP. A gênese do Depósito de baía (DB) na forma de terraço de superfície plana (Fig. 16A) está relacionada a ambientes de baixa energia, e até mesmo a paleobaías. Os sedimentos que constituem esse depósito são arenosos finos e lamosos (Fig. 16B), moderadamente selecionados, com presença de matéria orgânica, responsável por sua coloração escurecida e ocasional presença de estratificação (Horn Filho et al., 2014).

\subsection{Depósitos transicionais do Pântano do Sul (DL e DFL)}

Ao norte da praia e enseada do Pântano do Sul, na costa Sul da Ilha de Santa Catarina, afloram sedimentos do sistema deposicional transicional acumulados como produto das oscilações do nível relativo do mar ocorridas durante o Holoceno. 0 principal depósito da planície costeira do Pântano do Sul corresponde ao Depósito lagunar (DL) na forma de terraço lagunar (Fig. 17A) situado na altitude de $3 \mathrm{~m}$ acima do nível do mar atual. Seções colunares realizadas na planície costeira possibilitaram visualizar três estratos sedimentares distintos (Fig. 17B). 0 estrato de topo da sequência corresponde provavelmente a um Depósito flúvio -lagunar (DFL) na forma de uma planície lagunar, constituído de sedimentos areno lamosos, com expressivo teor de matéria orgânica. 0 estrato intermediário corresponde provavelmente a um Depósito marinho praial (DMP), constituído de sedimentos arenosos de coloração bege. 0 estrato da base representa o Depósito lagunar (DL) composto por sedimentos areno lamosos, com presença marcante de biodetritos carbonáticos (conchas e fragmentos de conchas).

\subsection{Praia da Lagoa do Peri (DLP)}

Corresponde a uma seção colunar realizada no setor de pós-praia lagunar (Fig. 18A) próximo à sede do Parque Municipal da Lagoa do Peri, em uma altitude de aproximadamente $1,5 \mathrm{~m}$ acima
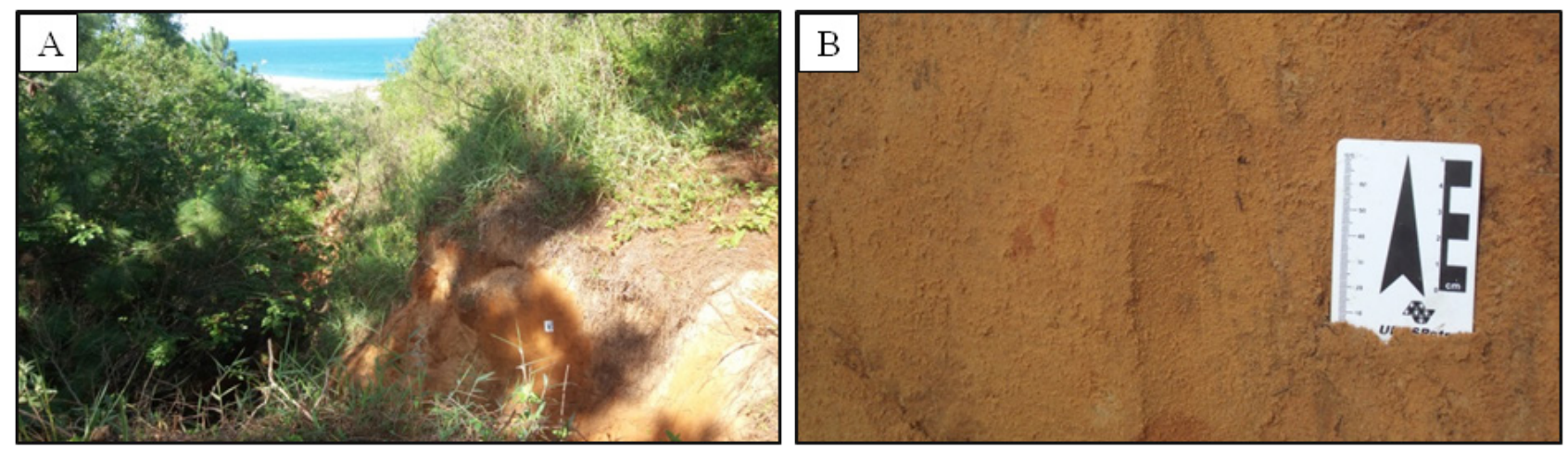

Figura 15. Geossítio Paleodunas da praia Mole. A) Ravina na paleoduna em meio à vegetação; B) Sedimento arenoso, bem selecionado de coloração marrom-alaranjado que constituí a paleoduna.

Figure 15. Geosite Paleodunes of Mole beach. A) Ravine in the paleodune in the middle of the vegetation; B) Well sorted sandy sediment, brown-orange color, that constitute the paleodune.
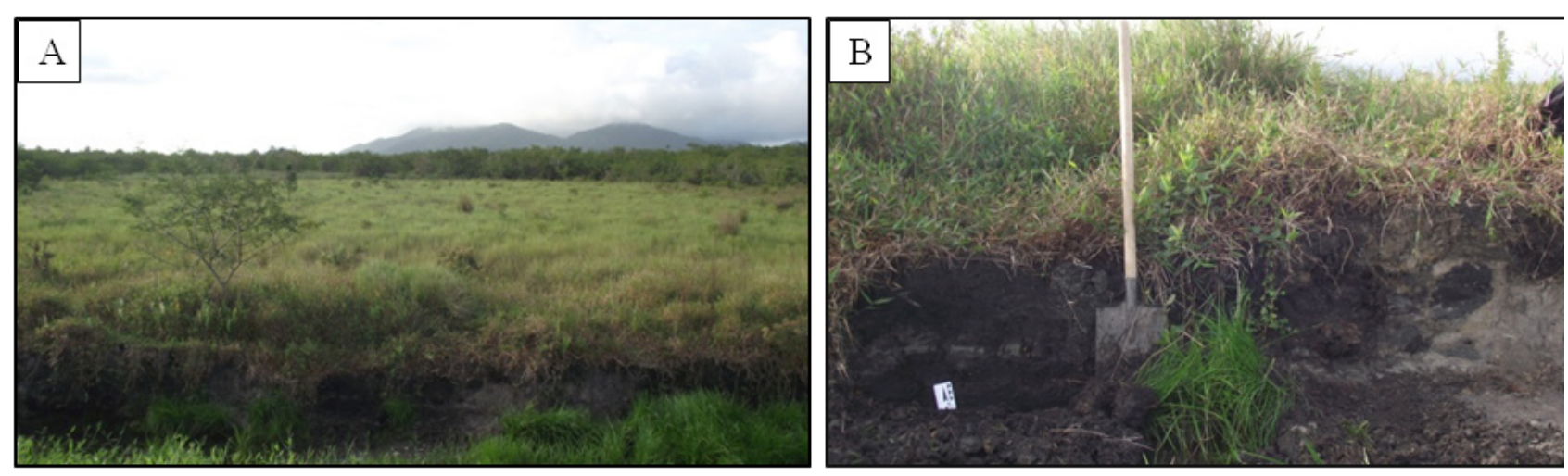

Figura 16. Geossítio Depósito de baía da Planície Entremares. A) Depósito de baía em forma de terraço de superfície plana; B) Contato entre o DB, à esquerda e o DMP, à direita.

Figure 16. Geosite Bay Deposit of the Entremares Plain. A) Bay Deposit in the form of a flat surface terrace; B) Contact between the $D B$ to the left with the DMP to the right. 

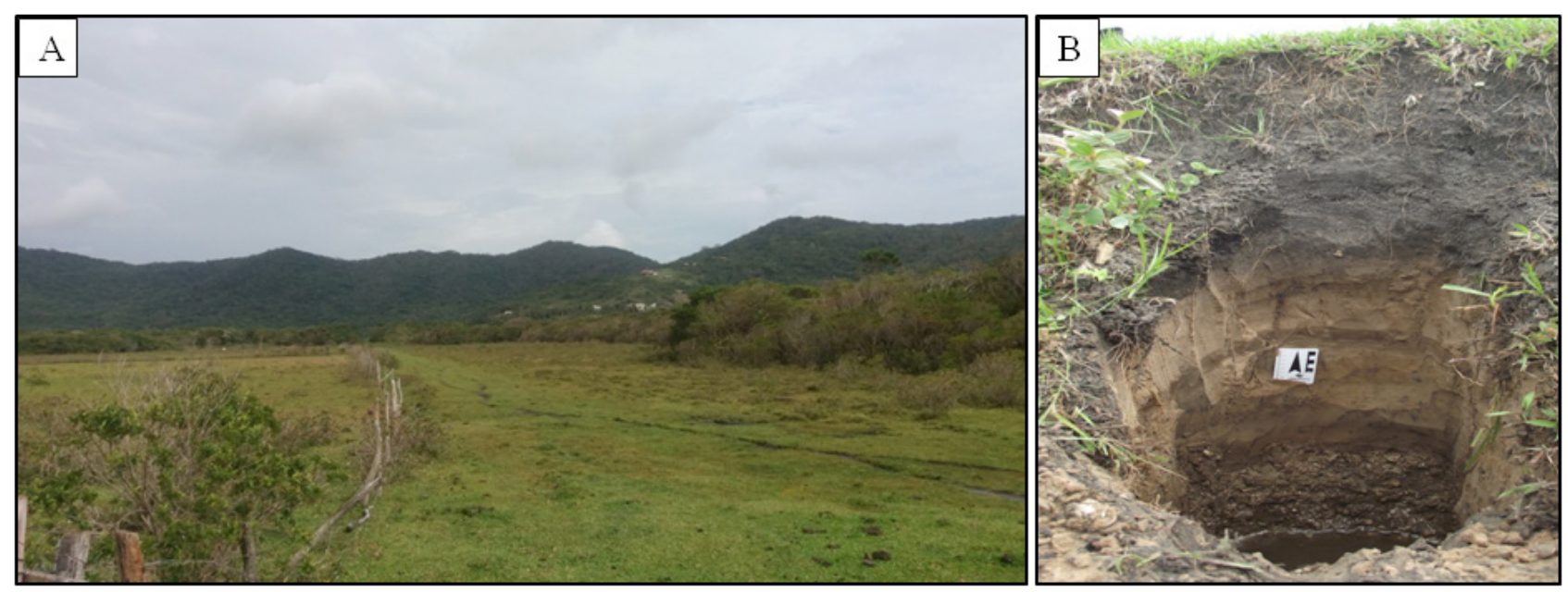

Figura 17. Geossítio Depósitos transicionais do Pântano do Sul. A) Terraço lagunar; B) Seção colunar que permite visualizar os três estratos sedimentares, no topo Depósito lagunar, no meio Depósito marinho praial e na base Depósito lagunar com presença marcante de biodetritos carbonáticos.

Figure 17. Geosite Transitional Deposits of the Pântano do Sul. A) Lagoon terrace; B) A columnar section that allows the observation of the three sedimentary strata: at the top the lagoon Deposit, in the middle the beach marine Deposit and at the lagoon Deposit with a marked presence of carbonate biodetrites.

do nível médio do mar. 0 Depósito lagunar praial (DLP) apresenta quatro camadas de sedimentos arenosos médios a grossos com grânulos, estratificados e presença de quartzo e minerais pesados (Fig. 18B). Do topo para a base, as cores dos sedimentos arenosos tornam-se mais escuras, bem como aumenta o teor de matéria orgânica. Localmente observam-se estratos de pequena espessura de sedimentos arenosos finos com concentração de minerais opacos e pesados.

\subsection{Areia escura da praia do Pântano do Sul (DMP)}

A praia do Pântano do Sul (Fig. 19A) é uma praia de enseada onde aflora o Depósito marinho praial (DMP), com placer de minerais pesados (Fig. 19B), exibindo expressiva proporção de grãos negros de óxidos de Fe-Ti constituídos, predominantemente por ilmenita, que se dispõe em finas camadas escuras, intercaladas com camadas claras compostas, predominantemente, por grãos de quartzo (Tomazzoli et al., 2007).

\subsection{Pontal da Daniela (DMP)}

O Pontal da Daniela (Fig. 20A e B) onde desenvolve-se o Depósito marinho praial (DMP) ou de baía praial, corresponde a uma língua de areia desenvolvida a partir do maciço cristalino, o morro do Forte. Atualmente, a língua avança na direção ENE-WSW e desvia para SW na sua porção distal em direção à Enseada de Ratones e estuário do Rio Ratones. Porém, a dinâmica evolutiva da areia do Pontal da Daniela é significativa. Em 1938, fotografias aéreas mostraram uma estreita língua de areia com uma orientação global para sul, que quase fechou a enseada da foz do Rio Ratones. Observações do mesmo perfil em fotografias aéreas de 1978 indicaram uma redução no seu comprimento, um alargamento em algumas partes da língua de areia e o desvio de sua porção distal para SW (Mendonça et al., 1988; Diehl, 1997).

\subsection{Tômbolo do Caiacangaçu (DMP)}

Tômbolo (Fig. 21A e B) formado por duas praias distintas, a praia de Fora e a praia da Ponta ocorrendo em ambas o Depósito marinho praial (DMP) ou de baía praial. O Depósito de baía praial da praia de Fora (Fig. 21C) é constituído de sedimentos predominantemente bioclásticos do tamanho cascalho-arenoso e ocorre subordinado à presença de grãos siliciclásticos à base de quartzo e feldspato. A praia da Ponta (Fig. 21D) apresenta areia grossa, moderadamente selecionada.

\subsection{Campo de dunas da Joaquina (DEH)}

O campo de dunas da Joaquina (Fig. 22A), localizado entre a Laguna da Conceição, a norte e a praia da Joaquina, a sudeste, na costa Sudeste da Ilha de Santa Catarina, originou-se do 
transporte eólico de sedimentos arenosos finos do Depósito marinho praial da Joaquina e plataforma continental interna adjacente, conformando dunas fixas, semifixas e ativas e mantos eólicos de diferentes gerações. As dunas, orientadas de sudeste para nordeste, variam de formas parabólicas e barcanoides, transversais (Fig. 22B) e longitudinais, aflorando igualmente uma série de depressões úmidas interdunares com lagoas efêmeras (Bigarella et al., 2015). 0 campo de dunas da Joaquina ou dunas da Lagoa da Conceição, conforme Bigarella (2000), constitui uma área de valor excepcional para o estudo de depósitos eólicos holocênicos (DEH), tanto do ponto de vista sedimentológico como geomorfológico, bem como para o estudo dos depósitos de cavalgamento oriundos das rampas de dissipação localizadas a leste, junto às encostas graníticas.
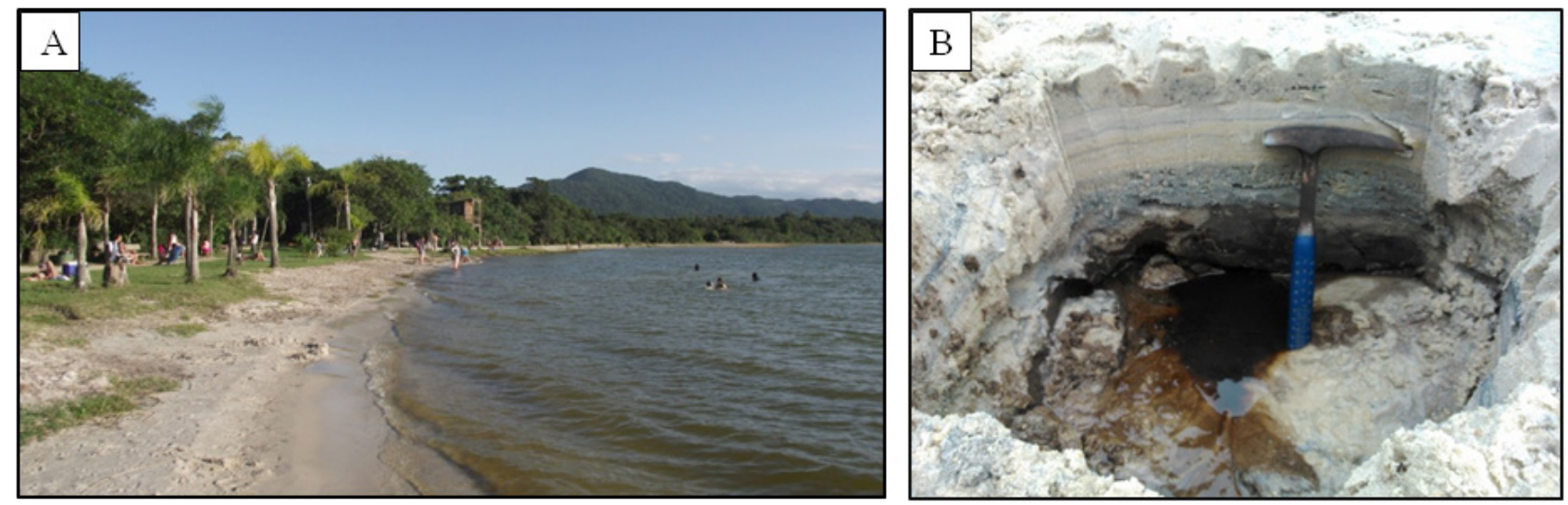

Figura 18. Geossítio Praia da Lagoa do Peri. A) Praia da Lagoa do Peri; B) Seção colunar, do topo para a base, as cores dos sedimentos arenosos tornam-se mais escuras em resultado do aumento do teor em matéria orgânica.

Figure 18. Geosite Beach of Peri Lagoon. A) Beach of Peri Lagoon; B) Columnar section, from top to bottom, the colors of sandy sediments become darker with the increase of the amount of organic matter.
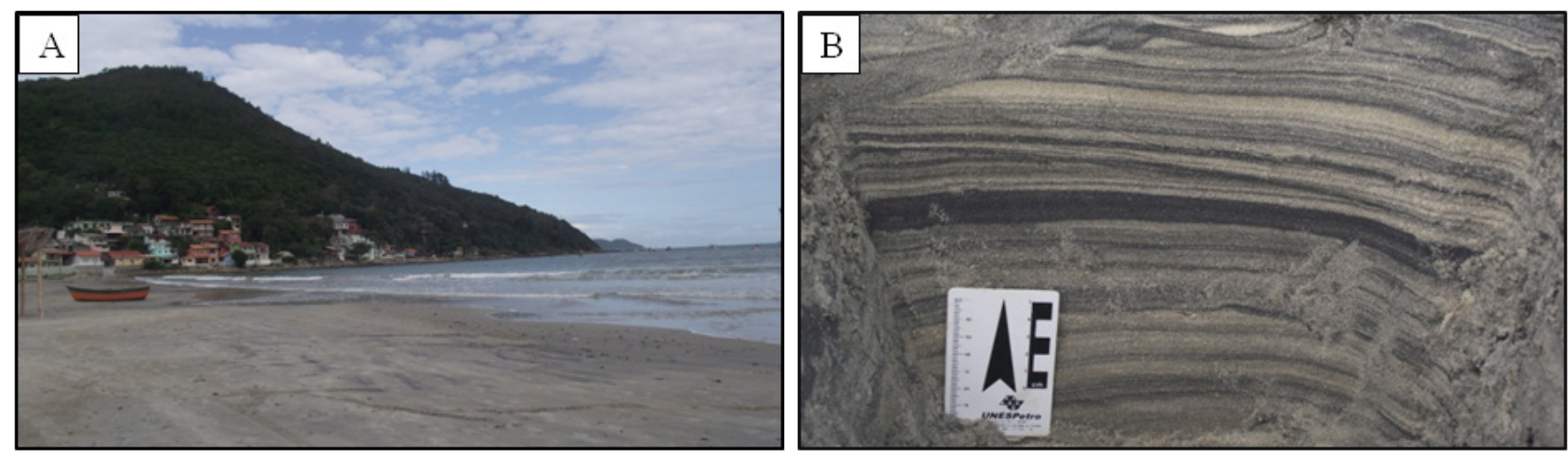

Figura 19. Geossítio Areia escura da praia do Pântano do Sul. A) Praia do Pântano do Sul; B) Seção colunar do Depósito marinho praial com camadas escuras de placer de minerais pesados intercalados com camadas claras compostas por grãos de quartzo. Figure 19. Geosite Dark sand of Pântano do Sul beach. A) Pântano do Sul beach; B) Columnar section of the beach marine Deposit with dark layers of placer of heavy minerals intermixed with light layers composed of quartz grains.
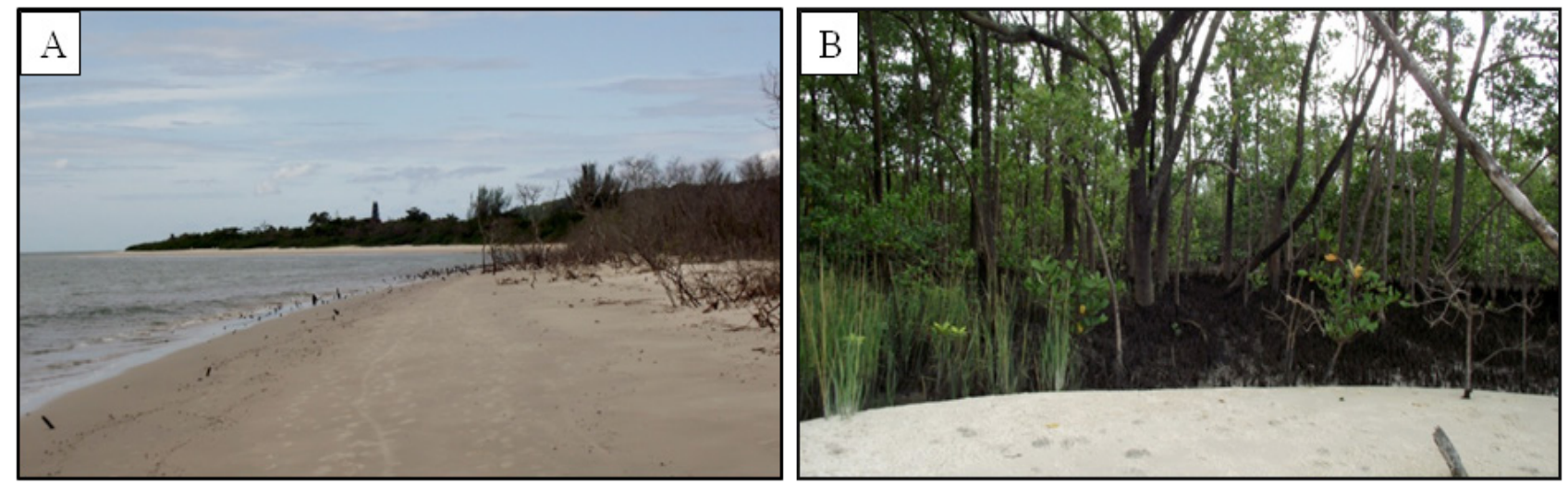

Figura 20. Geossítio Pontal da Daniela. A) Pontal da Daniela; B) Contato do Depósito marinho praial e Depósito paludial. Figure 20. Geosite Sand Spit of Daniela. A) Spit of Daniela; B) Contact of the beach marine Deposit and paludal Deposit. 


\subsection{Turfa da praia do Campeche (DP)}

A ocorrência de turfas na planície costeira está associada ao ressecamento de antigas áreas lagunares devido ao rebaixamento do nível relativo do mar, com o consequente surgimento de áreas baixas pantanosas, favoráveis à formação de turfeiras (Caruso Jr., 1993). A turfa da praia do Campeche apresenta uma sucessão de quatro estratos do sistema deposicional transicional aflorantes após rigoroso evento erosivo (Fig. 23A), observando-se da base para o topo, sedimentos arenosos finos do Depósito eólico do Pleistoceno superior, sedimentos turfáceos do Depósito paludial (DP) do Holoceno (Fig. 23B), sedimentos arenosos médios do Depósito marinho praial do Holoceno (Fig. 23C) e sedimentos arenosos finos do Depósito eólico do Holoceno que recobrem toda a sequência.

\subsection{Mangue do Itacorubi (DP)}

Localizado à retaguarda do Morro da Cruz, adjacente à Baía Norte da Baía de Florianópolis, em altitudes próximas ao nível do mar atual, aflora o Depósito paludial (DP), na forma de planície de maré (Fig. 24 A e B), cujos dados geocronológicos obtidos em sedimentos carbonosos com uso do 14C, revelaram idades de no mínimo 4,5 Ka AP (Holoceno) (Ayala, 2004). Os sedimentos mais superficiais do Depósito paludial são constituídos de lamas e areias finas, sobre o qual estabeleceu-se a sedimentação carbonosa do ecossistema manguezal. Ayala (2004) constatou a partir de dados de testemunho de subsuperfície com até $5,5 \mathrm{~m}$ de profundidade, que na área do manguezal do Itacorubi há a ocorrência de um vale inciso no embasamento com sedimentos de maior granulometria, associados a uma região de maior dinâmica. Inferiu também que a área do manguezal avançou em direção à baía Norte cerca de 120 m em 60 anos (1938 a 1998), apesar da interferência humana, o que demonstra a grande contribuição de sedimentação nesse ambiente nos últimos anos.

\section{Conclusões}

A partir do inventário e caracterização geológico-geomorfológica foi possível identificar os geossítios que compõem o patrimônio geológico do município de Florianópolis. Todos os geossítios
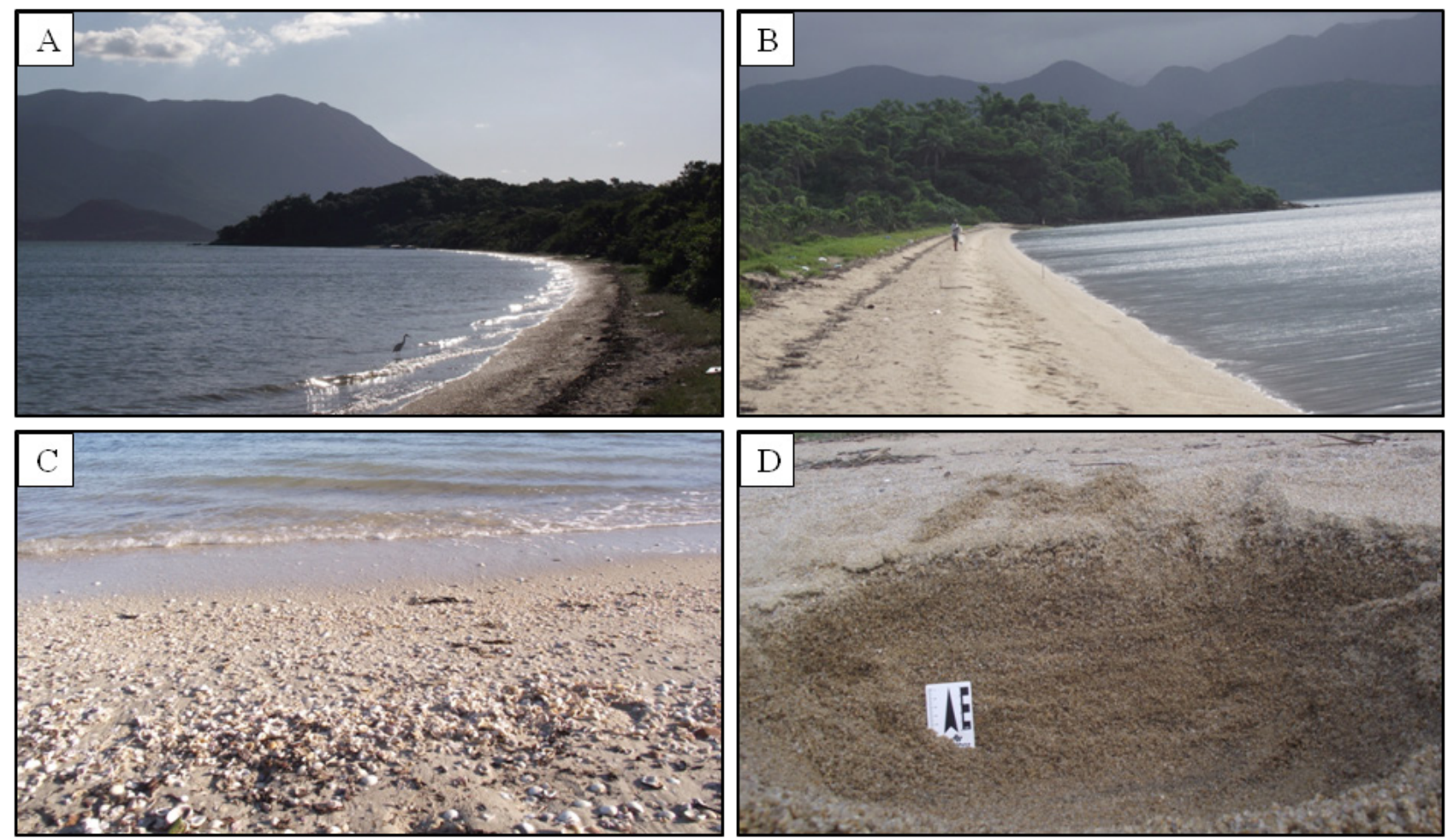

Figura 21. Geossítio Tômbolo do Caiacangaçu. A) Tômbolo avistado a partir da praia de Fora; B) Tômbolo avistado a partir da praia da Ponta; C) Areia da praia de Fora constituída de sedimentos predominantemente bioclásticos do tamanho cascalho-arenoso; D) Areia grossa da praia da Ponta.

Figure 21. Geosite Tombolo of Caiacangaçu. A) Tombolo seen from Fora beach; B) Tombolo sighted from Ponta beach; C) Sand of the Fora beach composed of predominantly bioclastic sediments of sandy-gravel size; D) Coarse sand of Ponta Beach. 

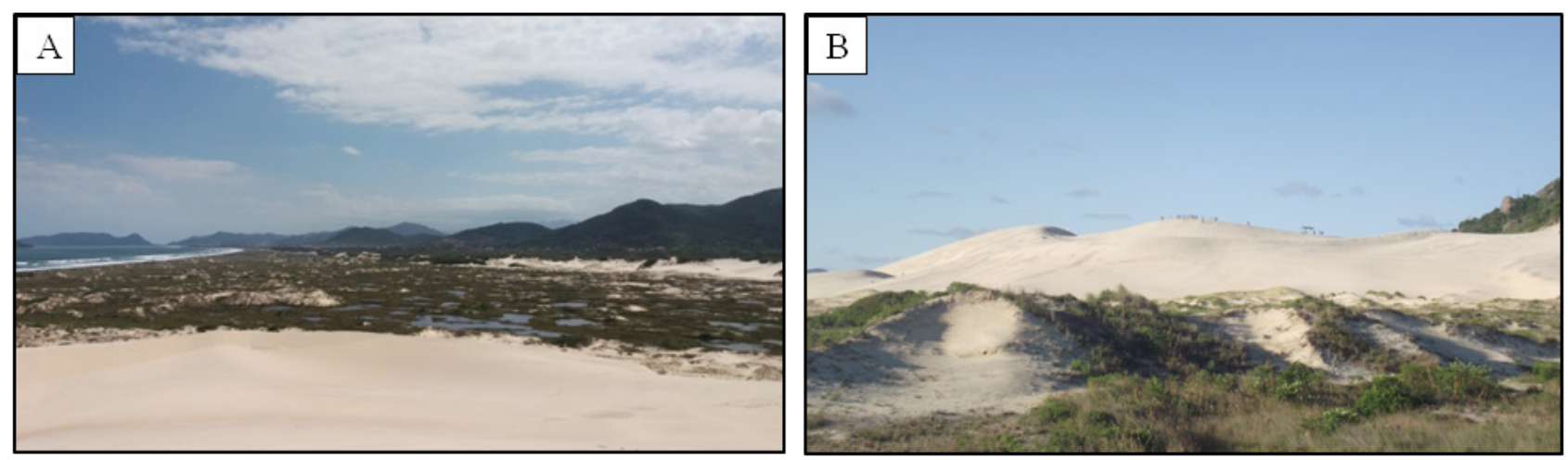

Figura 22. Geossítio Campo de dunas da Joaquina. A) Vista para sudeste do campo de dunas da Joaquina; B) Duna transversal a noroeste do campo de dunas.

Figure 22. Geosite Joaquina dune field. A) Southeast view of the Joaquina dune field; B) Transverse dune to the northwest of the dune field.

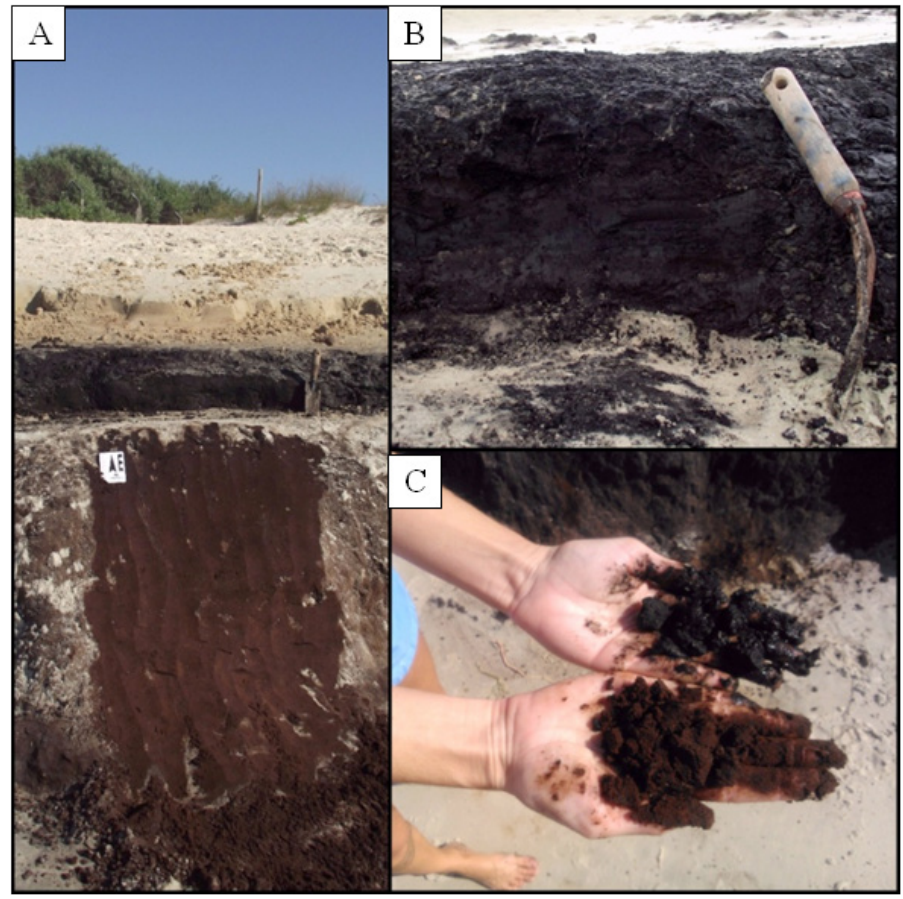

Figura 23. Geossítio Turfa da praia do Campeche. A) Sucessão de quatro estratos do sistema deposicional transicional; B) Sedimentos turfáceos do Depósito paludial do Holoceno; C) Sedimentos turfáceos do Depósito paludial e sedimentos arenosos finos do Depósito eólico do Pleistoceno superior.

Figure 23. Geosite Peat of Campeche beach. A) Succession of four strata of the transitional depositional system; B) Turfaceous sediments of the Holocene paludal Deposit; C) Turfaceous sediments from the paludal Deposit and fine sandy sediments of the upper Pleistocene eolic Deposit.
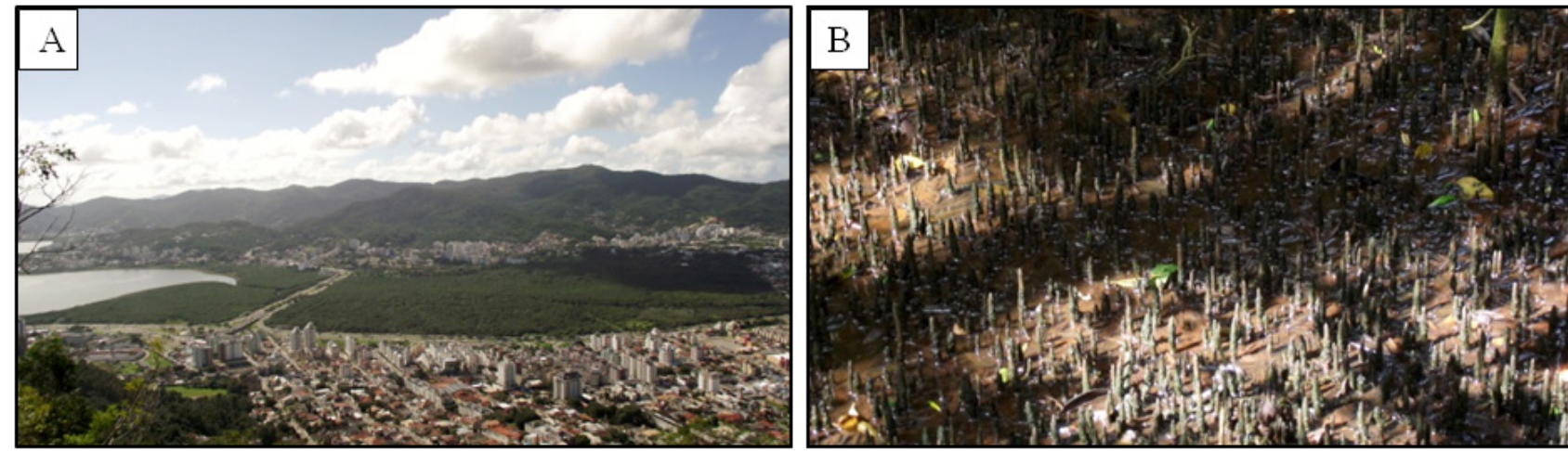

Figura 24. Geossítio Mangue do Itacorubi. A) Vista panorâmica da área do manguezal a partir do mirante do Morro da Cruz; B) Raízes respiratórias da Avicennia schaueriana que se desenvolve no Depósito paludial.

Figure 24. Geosite Itacorubi mangrove. A) Panoramic view of the mangrove area from the viewpoint of the Hill of Cruz; B) Respiratory roots of the Avicennia schaueriana that develops in the paludal Deposit. 
localizam-se na Ilha de Santa Catarina e contemplam os principais elementos da geodiversidade do município. A distribuição geográfica dos geossítios não é homogênea, a maioria situa-se no setor Centro-sul da ilha, em consequência da localização dos afloramentos mais representativos ou por ser nestes afloramentos que foram obtidas amostras que servem de suporte a publicações científicas. Por exemplo, a melhor exposição do Depósito eólico do Pleistoceno superior é o afloramento Paleodunas da praia Mole (11), apesar de esse depósito ocorrer de forma generalizada por todo setor Leste da ilha. Da mesma forma, apesar de existirem quatro manguezais na ilha, o único onde foram realizadas pesquisas sobre seus aspectos geológicos é o Mangue do Itacorubi (20).

Constatou-se que, apesar da maioria dos geossítios estar localizada em áreas protegidas, isso não garante a sua conservação devido à falta de fiscalização ambiental e de planos de manejo das unidades de conservação, que definam a gestão, o zoneamento e normas de condutas. Verificam-se ainda outras ameaças, como pichação e rampas de acesso à praia sobre os afloramentos. Todas as ameaças estão relacionadas com a falta de conhecimento sobre o patrimônio geológico, a geodiversidade e as geociências, como um todo.

Os próximos passos que devem ser realizados são a delimitação dos geossítios tipo área, a avaliação quantitativa do valor científico e do risco de degradação para, a partir dos resultados, delinear propostas de gestão do patrimônio geológico do município. Na elaboração de um plano de gestão voltado à geoconservação, os geossítios que não possuem nenhum tipo de proteção legal são os que precisam de uma ação mais imediata, visando estabelecer algum meio de proteção jurídica do local.

Contudo, em consequência da expansão urbano-turística, muitas vezes incentivada e autorizada pelas autoridades, os geossítios que estão em áreas protegidas também podem estar sob risco eminente. Logo, somente com a avaliação quantitativa, que permite aferir individualmente a vulnerabilidade de cada geossítio em relação aos fatores naturais e/ou antrópicos e comparar os resultados obtidos de todos os geossítios identificados, será possível reconhecer os sítios que se encontram com maior risco e que deverão ter ações de conservação prioritárias.

Na avaliação quantitativa do valor científico de um geossítio, a acessibilidade não é levada em consideração. Porém, um geossítio que apresenta fácil acesso é mais susceptível de ser danificado pelo mau uso dos visitantes do que um de difícil acesso. Ao mesmo tempo, a fácil acessibilidade possibilita o desenvolvimento de atividades educativas e/ou turísticas. Portanto, a acessibilidade dos geossítios precisa ser ponderada sob estas duas perspectivas, a conservação dos elementos geológicos e seu potencial uso educativo e/ou turístico.

É também necessário realizar o inventário de sítios de geodiversidade com potencial uso educativo e turístico, incluindo a sua avaliação quantitativa e risco de degradação. Os geossítios e/ou sítios de geodiversidade, que além do fácil acesso, apresentarem potencial educativo e/ou turístico, baixa fragilidade e vulnerabilidade, devem ser utilizados para atividades educativas e divulgação das geociências.

A classificação do tipo de geossítio (ponto, seção, área, mirante ou área complexa, segundo Fuertes-Guitiérrez \& Fernández-Martinez, 2010), durante a etapa de caracterização, contribui no delineamento da gestão, principalmente para o potencial uso turístico, uma vez que sugere como popularizar os locais, bem como a resistência aos impactos, ou seja, o quanto eles podem sofrer/danificar com a pressão turística.

A identificação do patrimônio geológico, em conjunto com a implementação de estratégias de geoconservação, poderão contribuir no fortalecimento da cultura e também no desenvolvimento sustentável das comunidades de Florianópolis. No entanto, para isso ocorrer, estas deverão conhecer esse patrimônio e participar na escolha das ações voltadas à geoconservação a serem executadas, pois, somente assim, virão a colaborar na conservação dos locais e irão se apropriar desses conceitos, os quais poderão ser inseridos em suas atividades econômicas.

Para tanto, o desenvolvimento de atividades educativas e interpretativas voltadas às geociências no município de Florianópolis, por meio do patrimônio geológico identificado, é imprescindível para mobilizar as comunidades a contribuir em sua monitorização e conservação. É conhecido que 
só é possível garantir a proteção do que se conhece e do que se dá o devido valor.

Um inventário de geossítios é apenas o primeiro passo para iniciar a geoconservação. A definição de propostas de gestão está relacionada com os resultados da avaliação quantitativa e de risco de degradação, e a educação, conscientização e empoderamento das comunidades em relação às Geociências é a chave para a conservação do patrimônio geológico.

Agradecimentos. À CAPES, pela bolsa de doutorado sanduíche concedida à Cristina Covello; aos professores da Universidade Federal de Santa Catarina e Universidade do Estado de Santa Catarina: Edison Ramos Tomazzoli, Gerusa Maria Duarte, Janete Josina de Abreu, João Carlos Rocha Gré, Joel Robert Georges Marcel Pellerin, Luiz Fernando Scheibe, Maria Lúcia de Paula Herrmann e Maria Paula Casagrande Marimon, que indicaram alguns dos geossítios elencados nesse trabalho.

\section{Referências}

Almeida, E.S. 2004. Geologia da ilha de Santa Catarina - SC. In: Bastos, M.D.A. (Coord.). Atlas do município de Florianópolis. Florianópolis: Instituto de Planejamento Urbano de Florianópolis, p.18-23.

Ayala, L. 2004. A relação do espaço na evolução morfodinâmica do manguezal do Itacorubi, Florianópolis, SC. Porto Alegre, 244p. Tese de Doutorado, Programa de Pós-graduação em Geociências, Instituto de Geociências, Universidade do Rio Grande do Sul.

Bigarella, J.J. 1975. Lagoa dune field, state of Santa Catarina, Brazil - a model of eolian and pluvial activity. Boletim Paranaense de Geociências, 33: 133-167.

Bigarella, J.J. 1979. The Lagoa dune field. In: Mckee, E.D. (Ed.). A study of global sand seas. United States Geological Survey Professional Paper, 1052: 114-134.

Bigarella, J.J. 2000. Parabolic dune behavior under effective storm wind conditions. Revista Brasileira de Geomorfologia, 1(1): 1-26.
Bigarella, J.J., Klein, A.H.D.F., Menezes, J.T. \& Vintem, G. 2005. Sub-tropical coastal dunes: examples from southern Brazil. Journal of Coastal Research, Special Issue, 42: 113-137.

Brilha, J. 2005. Património geológico e geoconservação: a conservação da natureza na sua vertente geológica. Braga: Palimage Editores, 190p.

Brilha, J. 2016. Inventory and quantitative assessment of geosites and geodiversity sites: a review. Geoheritage, 8(2): 119-134.

Brilha, J., Andrade, C., Azerêdo, A., Barriga, F.J.A.S., Cachão, M., Couto, H., Cunha, P.P., Crispim, J.A., Dantas, P., Duarte, L.V., Freitas, M.C., Granja, M.H., Henriques, M.H., Henriques, P., Lopes, L., Madeira, J., Matos, J.M.X., Noronha, F., Pais, J., Piçarra, J., Ramalho, M.M., Relvas, J.M.R.S., Ribeiro, A., Santos, A., Santos, V. \& Terrinha, P. 2005. Definition of the Portuguese frameworks with international relevance as an input for the European geological heritage characterization. Episodes, 28(3): 177-186.

Bruschi, V.M. \& Cendrero, A. 2005. Geosite evaluation: can we measure intangible values. II Quaternario, 18(1): 293-306.

Bruschi, V.M. \& Cendrero, A. 2009. Direct and parametric methods for assessment of geosites and geomorphosites. In: Reynard, E., Coratza, P. \& Regolini-Bissig, G. (Eds.) Geomorphosites. Verlag, München, p. 73-88.

Caruso Jr., F. 1993. Mapa geológico da ilha de Santa Catarina - Escala 1:100.000. Texto explicativo e mapa. Notas Técnicas, 6: 1-28.

Coratza, P. \& Giusti, C. 2005. Methodological proposal for the assessment of the scientific quality of geomorphosites. II Quaternario, 18(1): 307313.

Cruz, O. 1998. A ilha de Santa Catarina e o continente próximo: um estudo de geomorfologia costeira. Florianópolis, Editora da Universidade Federal de Santa Catarina, 280p.

Diehl, F.L. 1997. Aspectos geoevolutivos, morfodinâmicos e ambientais do pontal de Daniela, ilha de Santa Catarina (SC). Florianópolis, 147p. Dissertação de mestrado, Programa de Pós-graduação em Geografia, Departamento de Geociências, Universidade Federal de Santa Catarina. Ferreti, O.E. 2013. Os espaços de natureza protegida na ilha de Santa Catarina, Brasil. Florianópolis, 
349p. Tese de doutorado, Programa de Pós-graduação em Geografia, Departamento de Geociências, Universidade Federal de Santa Catarina. Florianópolis. Lei complementar n. 482, de 17 de janeiro de 2014. Dispõe sobre a política de uso e ocupação, os instrumentos urbanísticos e o sistema de gestão. Plano Diretor de Urbanismo do Município de Florianópolis. Florianópolis, 2014.

Fuertes-Guitiérrez, I. \& Fernández-Martinez, E. 2010. Geosites Inventory in the Leon Province (Northwestern Spain): A Tool to Introduce Geoheritage into Regional Environmental Management. Geoheritage, 2: 57-75.

García-Cortez, A.G. \& Carcavilla, L.U. 2009. Propuesta para la actualización metodológica del inventario español de lugares de interés geológico (IELIG). Madrid, Instituto Geológico y Minero de España, 61p.

GERCO. 2010. Plano Estadual de Gerenciamento Costeiro. Secretaria de Estado de Planejamento e Gestão de Santa Catarina - SPG/SC. Setor 3. Disponível em: <www.spg.gov.br/gerco.php>. Acesso em: 05 mar. 2015.

Grandgirard, V. 1999. L'évaluation des geotopes. Geologia Insubrica, 4:59-66.

Gray, M. 2004. Geodiversity: valuing and conserving abiotic nature. London, England: John Wiley and Sons, 315p.

Henriques, M.H., Pena dos Reis, R., Brilha, J. \& Mota, T.S. 2011. Geoconservation as an emerging geoscience. Geoheritage, 3(2): 117-128.

Herrmann, M.L.P. \& Rosa, R.O. 1991. Mapeamento temático do município de Florianópolis: geomorfologia: síntese temática. Florianópolis: IBGE/IPUF, 26p.

Horn Filho, N.O. 2006. Ilha de Santa Catarina. In: Muehe, D. (Org.) Erosão e progradação do litoral brasileiro. Brasília: Ministério do Meio Ambiente - MMA, 413-436p.

Horn Filho, N.O. \& Livi, N.S. 2013. Mapa geoevolutivo da planície costeira da ilha de Santa Catarina, SC, Brasil. In: Horn Filho, N.O. (Org.), Leal, P.C. \& Oliveira, J.S. 2014. Geologia das 117 praias arenosas da ilha de Santa Catarina, SC, Brasil. Florianópolis: Programa de Pós-graduação em Geografia, Universidade Federal de Santa Catarina, 228p.
Horn Filho, N.O. (Org.), Leal, P.C. \& Oliveira, J.S. 2014. Geologia das 117 praias arenosas da ilha de Santa Catarina, SC, Brasil. Florianópolis: Programa de Pós-Graduação em Geografia, Universidade Federal de Santa Catarina, 228p.

Horn Filho, N.O, Schmidt, A.D., Benedet, C., Neves, J., Pimenta, L.H.F., Paquette, M., Alencar, R., Silva, W.B., Vellela, E., Genovez, R. \& Santos, C.G. 2014. Estudo geológico dos depósitos clásticos quaternários superficiais da planície costeira de Santa Catarina, Brasil. Gravel, 12(1): 41-107.

IBGE. Instituto Brasileiro de Geografia e Estatística. 2016. IBGE Cidades@: município de Florianópolis. Disponível em: <http://www. cidades.ibge.gov.br/xtras/perfil.php?lang=\&codmun $=420540 \&$ search $=$ santa-catarina|florianopolis>. Acesso em: 18 jul. 2016.

Lima, F.F., Brilha, J.B. \& Salamuni, E. 2010. Inventorying geological heritage in large territories: a methodological proposal applied to Brazil. Geoheritage, 2(3-4): 91-99.

Luiz, E.L. 2004. Relevo do município de Florianópolis. In: BASTOS, M.D A. (Coord.) Atlas do município de Florianópolis. Florianópolis: Instituto de Planejamento Urbano de Florianópolis, p. 24-29.

Martin, L., Suguio, K., Flexor, J.M. \& Azevedo, A.E.G. 1988. Mapa geológico do Quaternário costeiro dos estados do Paraná e Santa Catarina. Série Geologia, 28, Seção Geologia Básica, n. 18, Brasília: DNPM.

Mendonça, M., de Carvalho, R.L. \& Silva, A.D. 1988. Estudo preliminar de geomorfologia costeira na ilha de Santa Catarina: Daniela e Ponta das Canas, município de Florianópolis-SC. Geosul, 3(5): 51-74.

Paisani, J.C. 2007. Depósito arenoso estabelecido diante de obstáculo topográfico na praia Mole - ilha de Santa Catarina, sul do Brasil: duna de cavalgamento ou rampa arenosa. Perspectiva Geográfica, 3: 129-138.

Pellerin, J.R.G.M., Tomazzoli, E.R., Bauzys, F., Bini, G.M.P., Égas, H.M. \& Wilvert, S.R. 2010. Mapeamento geológico-geomorfológico do setor norte da ilha de Santa Catarina. Revista de Geografia, 27: 248-261.

Pereira, P. \& Pereira, D.I. 2010. Methodological guidelines for geomorphosite assessment. Gé- 
omorphol Relief Processus Environ, 2: 215-222.

Pereira, P., Pereira, D.I. \& Caetano Alves, M.I. 2007. Geomorphosite assessment in Montesano Natural Park (Portugal). Geographical Helvetica, 62(3): 159-168.

Pralong, J.P. 2005. A method for assessing the touristic potential and use of geomorphological sites. Geomorphology: Relief, Processus, Environment, 3: 189-196.

Raposo, M.I.B., Ernesto, M. \& Renne, P.R. 1998. Paleomagnetism and 40Ar 39Ar dating of the early Cretaceous Florianópolis dike swarm, Santa Catarina island, southern Brazil. Physics of the Earth and Planetary Interiors, 108: 275-290.

Reynard, E. \& Coratza, P. 2013. Scientific research on geomorphosites. A review of the activities of the IAG working group on geomorphosites over the last twelve years. Supplementi di Geografia Fisica e Dinamica Quaternaria, 36(1): 159-168.

SANTUR. Secretaria de Estado de Turismo, Cultura e Esporte de Santa Catarina. 2012. Programa de promoção do turismo catarinense ação: estudos e pesquisas de turismo - estudo da demanda turística - alta estação 2012. Município de Florianópolis (errata). Sinopse janeiro/fevereiro/ março. Junho de 2012.

Scheibe, L.F. 2002. Aspectos geológicos e geomorfológicos. In: Pereira, N.V. (Org.). A ilha de Santa Catarina: espaço, tempo e gente. Florianópolis: Instituto Histórico e Geográfico de Santa Catarina.

Serrano, E. \& Gonzalez-Trueba, J.J. 2005. Assessment of geomorphosites in natural protected areas: the Pico's Europa National Park (Spain). Geomorphologie: Relief, Processus, Environment, 3: 197-208.

Silva, L.C., Hartmann, L.A., McNaughton, N.J. \& Fletcher, I. 2000. Zircon U/Pb SHRIMP dating of a Neoproterozoic overprint in Paleoproterozoic granitic gneissic terranes, southern Brazil. American Mineralogist, 85: 649-667.

Tomazzoli, E.R. \& Pellerin, J.R.G.M. 2014. Mapa geológico da ilha de Santa Catarina. Universidade Federal de Santa Catarina. Departamento de
Geociências, 1ํo edição. Disponível em: <http:// lmo.ufsc.br/files/2014/08/Geolog_Ilha6.pdf.>. Acesso em: 14 fev. 2015.

Tomazzoli, E.R. \& Pellerin, J.R.G.M. 2015. Unidades do mapa geológico da ilha de Santa Catarina: as rochas. Revista Geosul, 30(60): 225-247.

Tomazzoli, E.R., Oliveira, U.R. \& Horn Filho, N.O. 2007. Proveniência dos minerais de Fe-Ti nas areias da praia do Pântano do Sul, ilha de Santa Catarina (SC), sul do Brasil. Revista Brasileira de Geofísica, 25: 49-64.

Tomazzoli, E.R., Almeida, L.C., Silva, M., Mochiutti, N.F. \& Alencar, R. 2012. Espeleologia na ilha de Santa Catarina: um estudo preliminar das cavernas da ilha. Espelhe-o-Tema, 23(2): 71-85.

Urquí, L.C. 2012. Geoconservación. Madrid, Los Livros de la Catarata, 128p.

Wildner, W., Camozzato, E., Toniolo, J.A., Binotto, R.B., Iglesias, C.M.F. \& Laux, J.H. 2014. Mapa geológico do estado de Santa Catarina. Porto Alegre: CPRM, Escala 1:500.000. Programa Geologia do Brasil. Subprograma de Cartografia Geológica Regional.

Zanini, L.F.P., Branco, P.M., Camozzato, E. \& Regra, G.E. 1997. Programa de Levantamentos Básicos do Brasil, Folhas Florianópolis/Lagoa. CPRM/ MME. Brasília, 223p. 